\title{
Précis of the Regimental History of the 3rd Brandenburg Infantry Regiment (No. 20) During the Campaign of 1870-71
}

\section{Colonel H. T. Hildyard A.A.G.}

To cite this article: Colonel H. T. Hildyard A.A.G. (1891) Précis of the Regimental History of the 3rd Brandenburg Infantry Regiment (No. 20) During the Campaign of 1870-71, Royal United Services Institution. Journal, 35:163, 972-1027, DOI: 10.1080/03071849109416687

To link to this article: http://dx.doi.org/10.1080/03071849109416687

曲 Published online: 11 Sep 2009.

Submit your article to this journal $₫$

Џ Article views: 7

Q View related articles $\sqsubset$ 


\title{
PRÉCIS OF THE REGIMENTAT, HISTORY' OF THE 3Ro BRANDENBURG INHANTRY REGIMENT (No. 20) DURING THE CAMIPAIGN OF 1870-71.
}

\author{
Extracted by Colonel H. T. Hizdrard, A.A.G.
}

[The regimental histories of the German Army vary a good deal in value. Some of them are full of most interesting details, not only instructive, but throwing light on the campaigns in which the regriment has taken part. Of these, that of the 20th Regiment, of which a precis has been kindly under. taken by Colonel Hildyard, and is now put before the MIembers of the Iristitution, is one of the best. 'The only fault in the History is a deficiency of detailed maps and plans of the engagements and battles in which the refriment took part. There are in the Fistory incidents well worth noting other than those here described, but only a full translation would admit of all these being recorded. Colonel Hildyard has successfully extracted those of most value, and, in compliance with his wisb. I have exercised editorial functions in the shape of adding a few notes and some sketch plans. As regards the latter, it is only in connection with the Bittle of Vionville that there are at hand plans on a scale sufficiently large to make the text fully: intelligible.

The 20th lagiment was commanded by Colonel v.,Flatow, who, except when acting as Brigadier, served with it throughout the canpaign. It lelonged to the 11tl Brigade, Gth Dirision, of the IIIrd Army Corps. The 35th Regiment was the sister regiment in the Brigade. Colonel v. Rothmaler, commanding this regiment, was appointed. Hrigadier with the rank of Mijor-General; Lieutenant-General v. Buddenbrock was the Divisional Conmander. At the outbreak of the war Prince Frederick Charles was in command of the corps, and had brought it to the highest pitch of discipline and iraining. O On his appointment to the command of the IInd Army; of which the corps formed jart, Lieutenant-General v. Alvensleben II succeeded him:-L. A. II.]

THE order for mobilization reached the 20th Recriment at. 8 o'clock ou the morning of tho 16th July, 1870, at Wittenberg, on the Libe. The machinery was at once put in motion, and worked with the greatest regularity.

On the fifth day of the mobilizalion the Reserve men arrired from Berlim, Potsdam, and Jüterbog, and inmediately after their arriral on the drill ground they wero allotted to the sereml companies. It vas a pleasure to see tho cheerfulness with which these men came to rejoin the colours. No one wished to go to the Ersatr. battalion, ${ }^{2}$ and every one endearoured to be included in the mobile regiment.

After the arrival of this augmentation it was not possible to

1 “Das 3 Brandenburgische Infanteric-Regiment (Nr. 20) in den Feldzügen 1866 und 1870-71." Bg Major Kirchboff and First Licutenant Hrandenburg I. Berlin, 1831. Erngt Siegfried Dtiltler und Sohn. Prico \&.s.

2 Frers reginent on mobilization forms an Frsatz or depott battalion, to which are drafted eome of the Oficers, T.C.O.'s, and prirutes from the regiment.-ED. 
quarter the whole regiment in Wittenberg; a portion of tho sursounding villages were, therefore, occupied.

As early as the seventh mobilization day the regiment was able to report the mobilization completed. The short time that remained, after clotling the men, was utilized by the companies for drill. $\mathrm{By}$ regimental order, cach company was practised once in field firing with ball cartridge.

On the 22nd July orders were received for the regiment to more on the following das. With the exception of two, commanded by First Tientenants, all twelre companies of the regiment were commanded by Captains. Erery company bad, besides three Subaltern Officers ${ }^{2}$ and nine companies, a fourth. The Ersatz battalion was giren tro Captains and two First Licutenants as company commanders. A Captain was detached as Adjutant to tho 9th Dirision, and a First Lientenant as Adjutant to the 8th Infantry Brigade. The Commander of the fusilier battalion was transferred to the command of the Jager battalion of the corps. ${ }^{3}$

On the 23rd Jaly the regiment was mored by rail by Magdeburg, Brunswick (here coffec was provided), Hnnnover, Bielefeld, Hamm (where the men had a warm meal), Dortmund, and Cologno to Bingerbrück, where it arrired on the morning of the 25th, and was placed in cantonments at Planig, Bibelsheim, and Bretzenheim. Tho rest of the IIIrd Corps was coucentrated in cantonments at and about Kreuznach.

So as to facilitate the concentration of the 2nd $\Lambda$ rmy, the IIIrd Corps was now mored further towards the frontier by march. The beat, and the? hilly nature of the country, rendered the march very trying. On the 4th August, which was to have been a halt, the alarm was given in the early morning, and the regiment was mored forward again. The infantry had now approached to within some fer miles of the caralry divisions, which liad been pushed forward carlier to the frontier.

The IIIrd Army Corps was now so near the enemy that tho march was ordergd to be carried out in large badies, and cantonment guards posted.

On the 5th Angust the regiment went into cantonments at and about St. Wendel, where, on the following daj, a telegrem was reccived by the Colonel from Saarbrücken: "Inmediately by rail, entrain there whintever portion of the regiment can bo conresed. 5th Division in action."

The 2nd and the fusilier battalions were actually in St. Wendel, and were formed up at the railway station within a quarter of an

In these Subaltern Oficers, howerer, were included sir Portepeefähnrich. A portepeefähnrich is a soung man who has been a cadet, or is gerring in the ranks, and laring passed a special examinaticn, is ecrring as a candidate for a commissicn.-liv.

= In 1806 none of the mobilized companics had more than thrce Subaltern Oflicers.-II. II.

Including the regimentul and battalion Commanders and their Adjutants, there were 5.1 Officers rith the regiment. The etrength of the regiment is not giren, but probably each battalion was nearly 1,000 stroag, cxciusire of Omicers.-E:D. 
hour. T'he 1st, which occupied cantonments in a neighbouring village, was not long after them. But the first train, which lefi at 4 P.3. with the fusilier battalion, found the line blocked, and it was .7 .30 before tho last battalion left.

Consequently, only the fusilier battalion arrived on the field that erening, and it was too late to take any actire part in the action. The other two battalions joined it early on the morning of the 7th Angust; they had arrired at Saarbrück betireen 9 and 10 the previous evening, bat had, by mistake, been directed to 3 urbach.

The regiment profited by the capture at Forbach of French transport, inasmuch as company carts were allotted to it, which proved of immense service during the subsequent course of the campaign. Already, in the Palatinate, the pack horses told off for tho companics had been found unpractical for the transport rork required; but the regaiations did not admit of their being used in carts. The value of this was now recognized, and the use of carts encouraged.

The order was now giren for the adrance of the three armies tomards tho Noselle. 'I'be 2nd Army marched by the St. AroldNonceny rond, moving off on the 9th August; the 20th Regiment formed a part of tho adranced guard of the 6th Division. .Notrithstanding the excellence of the roads, the intense heat rendered the marches very trying.

On the 13th August the lst battalion reached Buchy; the 2nd battalion Silly, and were partly cantoned, partly birouncked, at those villages. The fusilier battalion wns on outpost duty, north-west of Buchy. On the 14th August the outposts had been pushed. forward, close up to the Moselle.

Marshal Bazaine had now only tro alternatives to choose between. Either he must offer battle, supported by the MIoselle and by the fortress of Metz, or he must retire by Verdun to Chalons, and cffect a junction there with MacMlahon's arns. As his retreat was already threatened by the wheel to the right of the German Army, he determined to adopt the latter course. Bat on the afternoon of the 14th $\Lambda$ ugust his rear was orertaken by the lst Army; and attacked at Colombes.

The 3rd Army Corps occupied on that day a position across the Nomény-Aretz road, fronting towards that fortress, to cover the flank march of tho 2ud Army, in the direction of Pont-i-MLousson. The Gth Dirision was posted in the ricinity of St. Jure. The fusilice battalion toot tho outposts at Iouvigns. The artillery engagement at Colombey could be distinctly heard in the bivouac.

On the morning of the 15th dugust there was not a Frencluman left on the right bank of the DIoselle. The advanced caralry patrols reported the French $A r m y$ in full retreat on Chalons. But delajed by tho immense train accompanying it, and by its columus being confined to two roads, its moro adsanced $\Lambda_{1}$ my Corps bad not retired by the erening further than the neighbonrhood of Gravelotto and Rezonville, whilst its rearmost corps were still close to Jfetz. Orders were issued from the headquarters of the German Armies for the 
znd Army to press forward on the 15th, to the roads leading from Metz, by Fresnes and by Etain to Verdun.

The 20th Regiment left its birouac at St. Jure at 8 o'clock. The order of march of the division was changed; the 12th Brigade formed the advance guard, the 11th Brigade the main body, with the 20th Regiment in rear. . Tho Seille was crossed at Cheminot, and at 2 P.3. the column halted at Longeville-les-Cheminot, north of this place, and dinners were cooked.

The division was to cross the Mroselle at Champey by a pontoon bridge, to be constructed by the Pioncers. The construction offered special difficalties on account of the swollen state of the river. While waiting the troops formed a bivonac, the 20th Regiment being situated in a meadow west of the road. Whilst the dinners were cooking Prince Frederick Charles rode up and said, "How are you getting on, my men?" The answer was, "Very well, your Highmess, only we should like to see the French soon." "Then," said the Prince, laughing, " jou can be satisfied. Only keep your legs well in haud to-day and to-morron, and you will overtake them, and cut off their retreat on Paris." "Shouts of joy resounded through the entire camp at the news.

$\Lambda$ bout 7.r.y. the march was resumed. All fatigne was forgotten at the prospect of getting up with tho encmy, and, accompanicd by cheerful singing, the colnmn marched by Bouxieres, up and down lill, to tho ligh bank of the Moselle.

Late in the evening tho head of tho division reached the bridge at Champey. But as it could as yet bo crossed only in file, the column following was put to the most irksomo and fatiguing delnys. At overy moment tho order was given, "Halt-Order arms." Soon the exhaustion of the men was so great that on tho order, "Halt!" all threw themselves down on the road, so as to rest their legs a little. But only for a few minutes. Then followed the order, "Slope, arms! March!" All struggled up and staggered on as if drank, from sleep. $\Lambda t$ last the road is left, a fire is scen in the distance, marking the position of tho bridge; and soon the turn of the regiment camo to cross. It was now midnight. The march was continued until 2 A.Mr., 16 th $\Lambda$ ugust, when a birounc was formed at Pagny.

After hardly two hours' sleep the troops were on foot again. At 4 A.s. the regimental wagons arrired, after crossing the river at lont-ì-ilousson, and coffce was prepared.

In the early dawn the Colonel of the regiment was to bo seen moving about the camp fires, encouraging the men, and expressing tho expectation that in the erent of a liglit they would do their daty and maintain tho credit of the regiment. From every side he was received with cheerful assurances that they could be depended on.

Shortly after 5 o'clock the order to fall in was given, and the advance resumed. Only the led horses, the medical and ammunition wagons, followed the battalions. The adranced guard was composed of $a$ cavalry regiment, a battery, and a brigado of infantry; the main body of three batteries, and a brigade of infantry.: In each case the batterics moved between tho two regiments of the brigade. 
On reaching Onville, the march was continued in a north-westerly direction through a hilly, wooded country, on the road to Mars-la. Tour. The heat was tropical, and the march most fatiguing. But the old Prassian sense of duty kept the Brandenburgers up; and impelled them forward.

At about nine o'clock a lant was made on the road, in a clearing in a wood. But hardly had arms been piled, and tho men stretched out their weary limbs in the shade, when the sound of guns was heard from the north-east.

"Stand to," was the order repented on all sides, and the ndvance was resurned towards the sonnd of firing. Buxieres was reached at n quickened pace, and a position taken behind the advanced guard brigade, which had already formed up.

The Commander of the Division was on a bill in front, awaiting reports from his cavalre, which had been sent forward towards Vionville to reconnoitre. The Arms Corps Commander, who was with the 6th Dirision on this day, had himself ridden forward with two squadrons of dragoons to reconnoitre the encuy, risible about Vion. ville and Rezonville.

The whole of the French Army of the Rhine was there, in the same strength and composition as on the previous das. Marshal Bazaine had originally intended to continue the retreat on Verdun, at 4 A.3., but difficulties liad been experienced, and he had postponed his march until the afternoon.

:General v. Alvensleben quickls grasped the situation. But he did not hesitnte a moment to lay hold of the superior enemy with his Aring Corps. He knew the tenacity of his troops, and could trust in his Brandenborgers to hold the enemy, at least until the neighbouring corp's should come ap in support, and the cnems had to be lield at all crents.

In the meantime the thunder of the guns sounded unceasingly in the ears of the regiment waiting behind the heights of Buxieres, inspirited by the prospeat of being engaged.

The artillery of the division was already hotly engaged in adrance. It had joined the batteries of the 5th Caralry Division, which, by their unexpected appearance, had succeeded in driving back the encmy's caralyy in wild hasto on to the infantry, in their camps at Rezonville. Now, however, these bodies of infautry bad rapidly got under arms, and advanced to occupy the positions indicated beforehand, and prepared for the defence.

These positions extended from the platenu north of Vionville by Flavigny to the St. Arnould IVood. The Cth Corps (Canrobert) was posted north of the Metz road; the 2nd Corps (Frossard) was south of it.

Here, on the enemy's left flank, the infantry engagement broke out at this moment, for the 5th Division, which had crossed the Moselle at Noreant the previous night, had mounted the platean from Gorze, and on debnuching came upon the 2nd hostile Corps.

As reports eoou reached tho General Commanding from tho 5th Division that pointed to the retirement of the French in a northerly 


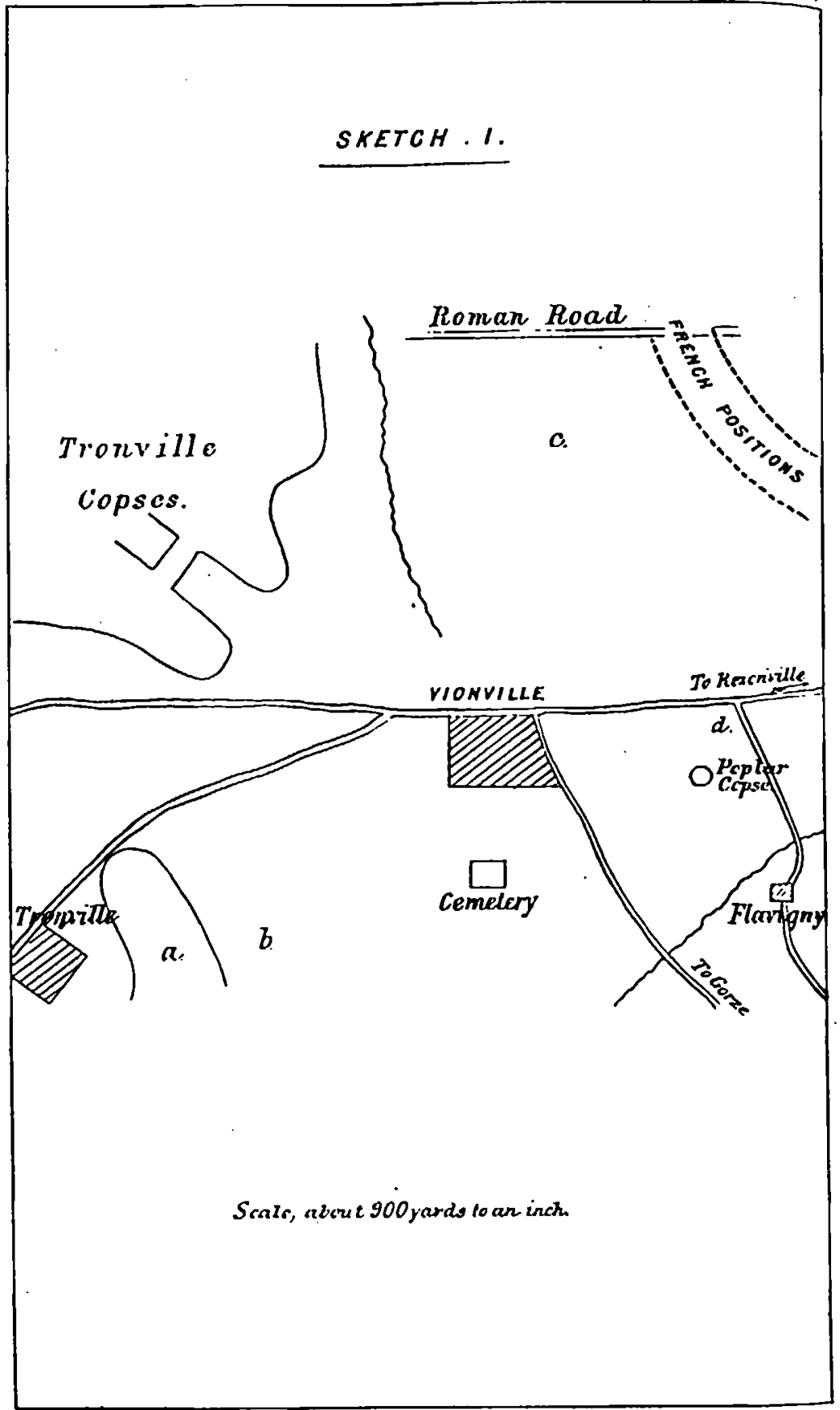


direction, the 6th Division was ordered to adrance by Mars-la-Tour on Jamy, in order to cut the enemy off from any outlet to the westward.

The adrance was continued in rendezvous formation. The din of the battle commeveed became louder and louder. With the thunder of the guns was now mixed the rattle of the ruitrailleuses, and tho crackle of the small-arm firc. At this time nothing was visible of the engaged troops. A halt was made on a level with the village of Tronville. It now appeared that the further advance in a northerly direction on Jarny was no longer required by the circumstances. The attack would hare to be made eastwards in the direction of the Iretz-Rezonville road. The direction was changed (see Sketeh 1).

The Divisional Commander rode forward with his Staff towards Vionville to reconnoitre.

From time to time small clouds of smoke could be seen dancing high in tho air. French shrapnel exploded with a crackling noise and struck the groand, but without reaching the flat heights belind wbich the brigade was situated. As yet the impressions were not sufficiently serious to stop the moutlis of the jokers. "Levi, checr up," said a private of the 2nd company to his front rank man; "wo are going to the fair ; they are tearing ap the culico." There was soon enough to be an end of merrinent and wanton wit. The mouth that inade the above remark was closed for ever before an hour had passed. "Packs off !" ordered the battalion Commanders. A fow minutes later, on the order of the brigade Commander, Fusilier Regiment No. 35 , which was in the lst line, wns deployed iuto fighting formation. The 20th Regiment followed at 2ud line distance, laving the fusilier battalion on the right flank.

Hardly had the regiment reacbed the eastern slope of the brond declining ridge, and thus come within sight of the enemy's batteries posted beyond the village of Vionville, when a shower of projectiles was launched upon it. Shells plunged into the ground in front of and between battalions, sbrapnel burst high over the men's heads; it appeared almost to be a miracle that the regiment did not suffer héavy losses.

On tho nrder of the regimental Conmander two companies from each battalion were now throwu forward. The objectives giren for tho advance were: for the 2nd battalion the village of Vionrille; for the 1st battalion the battery situated at the south-western corner ; for the fusilicr 'battalion a wall south of the village, which proved to belong to the cemetery.

The battalious adranced against the objectives designated in the quickest time. The compauies were on the point of extending their leading half-züge, when an order came from tho division Commander to the regiment to keep the two musketeer battalions in close order, to form the general reserve of the dirision. This was

1 The regiment passed south of Tronrille and clcse to the rillage, and at this time wes about the point marked " $a$ " on the eletch.- Fiv.

2 That any French batters wae crer at this point is most improbable. So far as I hrow there is ro confirmation any where of this atatement in the text.- ED. 
carried out in accordance with the orders convesed bj the $\Lambda$ dju. tants. The companies which bad abready suffered losses from the artillery fire had in a fow minutes assembled again, and were placed in tho hollow soutli-west of the village. ${ }^{3}$ Tho 3rd company alone, which had the shortest line to go to rench tho rillage, and bad hurried forward in advance of the other companies, was at the time the order reached it already hotls engaged, so that it could not be withdrawn from the fight.

In the meantime the fusilier battalion had advanced in the direction of the villnge cemetery. The 11th and 12th companies were in advance; the 9th and 10th companies followed in closo order as supports. The battalion Commander was with the 1lth company."?

When the losses increased, and besides the shell fire the distant firc of the Chassepott rifles began to take effect, the leading halfzügo were extended. In this formation the battalion went down into the hollow that runs soutl-east, past the village of Vionville. ${ }^{3}$

For a few minutes the battalion was here ont of sight of the enemy. 'The losses appeared to diminish ; but a moment later, when the battalion had reached the edge of the undulation and entered on the open ground towards Flarigny and Rezonville, a reritable hail of projectiles of erery kind poured down on the fusiliers.

In spite of the cuormous gaps caused by tho enemy's lead, the fusiliers pressed courageously on. The order of the Captains to extend and to reinforce the shirmishing line were carried out quietly and with precision. 'Ihe two extended half-züge of the llth company were reinforced by the 5th zug; those of the 12th company by the 7th zag."

In the same manner the leading zïge of the 9th and 10th companics were extended.

The llth compang had pressed further forward on the northern slope of the heights, and now observed that it had lost its origiual direction, for tho cemetery las to the right. In order to correct this mistake, perhaps also moved instinctirely by the desire to find on the higher ground some shelter for a moment from the destructive fire, the company brought the left shoulder sharply forward. Tho ucxt moment the whole company threw themselres down close to the cemetery wall. Only a brief moment of rest was accorded. Then camo the order, "Up, double march ; down the slope." Detachments of the 35th Regiment, which n short time previous had been driren back behind the cemetery wall by the fearful fire, joined the company. 'The appearance of this insignificant support sufliced to give the brare 35 th the impulse for a fresh adrance.

1 About the point marked " $b$ " on the skcteh.-Ev.

- Apparently the 11th company was on the right of the 12th compans.-Fiv.

3 The map in the oflicial account, $5 A$, shows thint the ralles referred to is the one running $\boldsymbol{H}^{2}$... between the village of Vionville and the cemeters.-ED.

- Each of the twelrc companies of a regiment is dirided into three züge. In cach company onc of theso was callecl the Schutzenzug. The remaining cight were numbered consecutirels from right to Icft through each battalion. The züge of the 1st, 5 th, and 9 th companies were numbered 1 and 2 , those of the $2 n d, 6 t h$, and loth companies 3 and 4 , and so on.-ED. 
The furious fire concentrated at this spot from Flavigns, from the copse of poplar trees cast of Vionville, and the troops behind, west of Rezonville, was traversed at the double. The company then adranced uninterruptedly up into $n$ gap in the line of the 35th. The right wing of this regiment had its front towards Flavigny; the left wing fronted more to the north to the road.

On the right, near tho latter troops, the 11th company now took its place, and with them occupied a meadow, through which flowed a small stream north of Flavigny, with the front towards tho copse of poplars.

On the way to its present position the company had lost no less than 50 killed and wounded, of whom 4 wero Olficers, viz., 1 Captain, I First Lieutenant, and 2 Second Lieutenants. The battalion Comnander and the company leader had their horses shot under thern immediately beyond the cemetery.

The 12th company had advanced at first on the same alignment as the 11th company. Coming out of the hollow, its ranks also were dreadfully thinned in the shortest time. The impression produced by this led to the laalf right turn of the 11th company not being noticed. Following the principal line of the enemy's fire, the company adranced directly on the bridge between Vionville and tho cenctery, in a direction which led to the south-castern corner of the village. Nothing was now to be seen of the enemy.

Tho 9th and 10th companies now brought their right shoulder forward on the supposition that the battalion commander was with the 12th companf, and had ordered the direction of attack on the rillage. They pressed forward in the first instance against a farm which las south of the village, in the immediate ricinity of the charch. Frorn there they tarned, accompanied by detachments of the 35th Regiment, towards the castern outlet from the village.

The occurrences described above led to the 11th company fighting alone, separated from the remainder, during the first hours of the battle.

We left the 1st and 2nd battalions at the moment when, in accordance with saperior orders, thes were nssembled as a reserve. After the battalions had been balted a short time in the hollow between Tronville and Vionville, they were pushed forward, by the order of the regiment Commander, on Vionville, in ordor not to lose their distance from the first line, and were opened out during their advance.

They had arrired at 200 paces from the village, when the Division General Staff Officer brought the order that the 2nd batialion was to more in a northerly direction with a riew to its special employment: The General was waiting for the battalion Commander at the tall poplars on the road, west of the village, in order to give him more detailed instractions.

At the same time the lst battalion was placed at the disposal of the regiment Commnnder, and receired the order to adrance between the village and the cemeters. The battalion Commauder placed the 2nd and 4th companies in the first line; the lst company followed as reserre. 
Alrendy, during the deployment, the losses becanue sensible. An Officer of the 2 nd company was sererely wounded; the regiment Commander and the fifth Field Offieer' bad their horses shot under then. The Colonel remained on foot during the remainder of the fight, and ordered the other Field Officers to dismount.

The battalion sonn entered the space swept by the enemy's bullet3. Death reaped agrain here a fearful harrest. A shell tore off the top of the colours. Directls afterwards the battalion Adjutant fell, screrely wounded. But the cry was still "Fomeard, into the adlanes.l fighting line."

At this point, we must recall the participation of the 3rd cumpany in the struggle, in order to specify the situation in which the lat battalion found itself in its further adrance.

We have alreads seen above, that the 3rd company did not receire the order for the battalion to assemble. While pressing forward in the meadowland, close to the southern border of the village, it had the good fortune to get on with comparatirely small losses across the Vionville-Gorze road as far as a strip of meadow, from which the copse in front was fired on for a short time. As the fire frum the copse appenred to become weaker, the company leader thought he might gain possession of it by a rapid advance, as the general nttack to the left had not progressed yet bejond the border of the village. An attenipt was made to gain the wood at the double by mcaus of the exteuded zug, wbich was reinforced by the 3rd zug of the company. The company renched the edge with heary losses.

Immedintely afterwards, a company of the 35th Regiment pressed ap on the left. Iloth companies endearoured to gain ground further forward; but at this moment a whole French brigade (Pouget) advanced against tho wood and opened so destructive $n$ fire on it that its maintenance by the two wenkened companies was not to be thought of, especinlly as the wood, being composed of slender poplar stems, did not offer the slightest corer.

The 3rd company was forced te retire, with great losses, in the direction of the village. The companj leader still held the Vionville road with a portion of it, while the other purtion had to retire to tho farm ncarest the village. The tactical order of the company was for the moment relaxed. The company had lost seventeen killed and forty-three wounded in the attack of the copse, amengst them three Officers.

In the meantime the attack of the 11th Brigade had led detachmeuts of troops on all sides to points from which the copse and the rond lying worth of it could be brought under fire. Companies of the 35th Regiment pressed forward concentrically from the village of Viorville, and to the right in the direction of Flavigny, and threw themselves down, where the ground offered a slight cover, for a short fire action.

At this stage of the engagement, our lst and fusilier battalions came into the fight also.

1 This Oflicer is a Field Oficer attached to the reginent mainly for adminis. trative purposcs.-Eiע. 
The 1st battalion had extended the leading züge of the 2nd and 4th companies, and found itself soon after crossing the Vionville. Gorzes road on a level with the advanced fighting line. The 12th company, which had pushed itself up in the meantime, joined the left flank of the 1st battalion.

The adrance was continued withont interruption in tho direction of the copse, from which the enemy delivered their Chassepôt fire with frightful precision into the ranks of the Brandenburgers, whilst shell after shell was thrown into the assanlting troops from the heights hejond the road. The zingo which were still in close order reinforced. The first company was already brought up on the right flank of the battalion in the advanced line. The 2nd zug went forward; tho other two remained a little longer in close ordet. $A$ company of the 35th Regiment had been pushed up between the and zog and the 4th company.

Un the left the 9tin and 10th companics, which came out from the border of the village at the moment of the general adrance, joined the 12th cumpany.

The Colonel of the regiment, who directed personally the attack on the heights east of the wood, had, thercfore, united six of his companies bere.

$\Delta$ general harma resounded. The copse and the elevated ground cast of it wero reached; tho enemy gare way before the attack, and 2etirch orer the road in a nortberly direction.'

But alrcady fresh masses of French troops were drawn into the fighting line, which corercd the ground abont the poplar copse with renerred showers of lead.

It is not possible to remain here. Aireaty some of the troops bregan to waver. $\Lambda$ retrogrnde morement must ineritably lcad to destruction, unless a line of cover could be reached. "Forward," thrrofore, was the cry on all sides, "up to the road."

A new. lusty harrah! and the roaci also is in the hands of the Binndeuburg Regiments. It was just noon. $A$ sercre and bloody picce of work had been acconplished. The eneray had been driven out of his adranced positions into the main position on the edgn of the platenu (see sketch).

'Tinis success had certainly been purchnsed by the reginent with henvy sacrifees. On their way to the road the six companies had lost in killed and wounded 19 Officers and about 300 men.

On the rond all endearoured to get as far as possible under corer.

1 The following note in the origind sems worth inserting :-

When this elerated ground was taken the shooters threw themselrez dorn. Colonel r. Flatow with his Adjutant, First Lieutenant Wegener, and MIajor r. Pircl, the Commander of the fusilier battalion, rerc standing close belind the men. Suddenly Lieutenant Wegener fell and etruggled conrulsirely. "Sliot througl the heart," remarled the Jlajor to Colonel r. Flator. After a few minutcs Wegener made signs to hare his neck loosene t. This was done, and a few minites later loe wns stauding up fresh and unlurt. It appeared that when stancling with lips parted to take breath on the eummit, a Chassepot bullet had prssed between them, literally taling amay his wind. $\Delta$ fer dajs later a thick sear slioned itself on cach lip.-Ev. 
The skirmishers ensconced themselves in the ditch on the south side, and the poplars on the road offered some protection, though little, owing to the small girth of tho trees. Supports wero no longer at hand.

As the regiment Commander passed along the firing line, he found the colour-bearer of the lst battalion, with colours, alone 30 paces belind. If he had been hit, and the battalion had moved on, the colours would have remnined there. He was, therefore, ordered up with the colours into the firing line.

A stationary fire action was developed here, with the superior enemy posted on the brow of the plateau, whoso infantry were materially assisted by the fire of batteries posted on the rising ground in rear. Tho engagement here continued to causo much loss. The masses of the enemy posted on the prolongation of tho road in front of Rezonville, enfiladed the road, and no cover was available against this fluuk fire.

'The first care of the Commanders was now directed to re-establish. ing some order amongst their troops. In the heat of tho combat they had frequently become mixed up. Men of the 20th, 35th, and 61th were mixed; whole ziige were found in companies to which they did not belong.

While the Colonel of the regiment was giving orders regarding this to the fusilier battalion he was slightly wounded, and also tho regimental Acljutant.

A complete assombly was naturally out of the question on account of the coutinued serere fire. It had to suffice to reunite those belongiug to the same units, where this could be dono without mach movement. Especially scattered individaals managed to rejoin their companies, crawling on their stomachs.

The cxcellent bearing of our men in these trying lours, when they had to remain inactive while death was demanding fresh sacrifices to riglit and left of them, cannot be sufficiently acknowledged.

Ve will now turn to another part of the battle-feld, and look for our 2nd battalion' there. Wo left it as it was ordered by the Division Commander to the western issue of Vionville. On the arrival of the battalion the Division Commander was no longer there.

The battalion Commander, therefore, sent it behind the largo battery posted across the road, so as to get it out of the way of the enemy's heary shell fire, and to avoid wasking its own artillery. In the meantime ho went hinself to look for the Dirision Commander. After a long search he met the Division General and Staff Officer, who brought him the order for the battalion to be mored up north of the road into a wide gap that existed between the 1st and 2 nd batta. lions of the 24th Regiment. ${ }^{2}$

This regiment was engaged on the extremo left flank of the fighting line, between Vionrille and the Roman road, in a struggle as keen as it was -bloody, with far superior and erer-increasing masses of

${ }^{1}$ The 2 ad battalion was only thrce companics strong on the day of Vionville. The 6th compuny was detached as escort with the dirikional baggage.

"About the point marked " $c$ " in the eleteh.-ED. 
the enemy. Deployed in a long line, the further.adrance of the brave Q.4th had now been brought to a standstill. Its ranks had been fearfully thinned. The grenter portion of the Officers were stretched on the battle-field, either killed or wounded.

In order to reach the point indicated, the Commander led his threo conpanies, with the sth company forming tho advanced guard, through tho Tronville wood, quitting it on the castern side, in a northerly direction, until the fighting line was reached.

In advaneing from the wood, the 5th and th companies formed the adranced line. They debouched from the rood on to tho open gronnd with their adranced züge extended. Although tho open space up to a small strip of meadow at the bottom of the valley was covered at the double, on account of the rapid fire directed npon the companies from all sides, the losses were, notwithstanding, considerable. They increased when the companies surmonnted the opposite slope of the small ralley. By the time the alignment of the 24th was reached most of the Oficers were hors de combat. Besides the battalion $\Lambda$ djutant, the sth company lost its Commander and two otherOfficers.

As tho battalion was too weak to prodnco a change in the situation of the figlit, it took part in the fire action of this flank, tho men lying down.

The eneny was posted abore on the edge of the plateau and the border of the wood, the other side of the Roman road, in enormous superiority. Fired on from the front and the left flank without intermission, the companies, now entirely extended in shirmisher lines, suffered fresh losses.

In order to strengthen the fire, the battalion Commander ordered the 8th company, which had been left as support in the hollow in rear, to extend and adrance into the firing line. The 7th and 8 th sïge took their places on the left of the 7 th compans.

Soon this company began to gain ground to the front, following the example of its Conmander. This was facilitated by the other two companies almost at the same timo getting forward about 200 paces, the men'crawling on one by one, so as to aroid the fire.

But the fight at this spot was too unequal. The fire of the needlegan was here in no respect superior to the Chassepôt. To this was added the unusual difficulties of the gronnd, which offered only most incomplete corer.

Notwithstanding this, a sergeant of the 7th company succeeded in leading his zug, the Officer commanding which had been wounded, to a point nearly 200 paces in adrance of the general front. This was in a field situated somewhat higher than the ground generally, where three single trees and tho hedges abutting on them gave some corer to the men, who took shelter behind them. 'The 8th;zug of the 8th company made its way to the same spot. It was possible from there to bring the enemy on the Roman road under an effective fire.

Repeated attempts to bring up fresh detachments failed on account of the watehfulness of the cneny, who swept the entire ground with his bullets whenerer eren a fer men rose up. As this led to fresh 
and heavy losses along the whole line, these attempts had to bz temporarily abandoned.

In the meantinıs the sitnation of the troops at this place becam? worse and worse. It wonld lare been an easy matter for the onemy with their entire 6th Army Corps to breat thrsigh the thin lines by a detcrmined adrance.

Towards 1 o'clock, however, the left flink, receired a further rein. forcement by the arrival of $2 \frac{1}{2}$ battalions of the $X \mathrm{tl}_{2} \mathrm{Army}$ Corps ( $1 \frac{1}{2}$ battalions of the Oldenburg Infantry Regiment, No. 91, and 1 battalion of the Regiment $N(1.78)$.

These troops endeavourcd to advance from the north-eastern border of the 'l'ronville copses, on the extreme left llank, against St. Niarcel; but all their attempts, conducted with tho greatest energs, failed here alsn, owing to the numerical superiority of the ene:ay, who outflanked the adrancing troops and inflicted on them heary losses with their long-runge Chassepôts, at distances at which it was not possible to return an effective fire with the necdle-gun.

'The positions on the border of the wood were, however, maintained, notwithstanding that tho arrival of considerable French reinforcements could be observed.

'The French seemed gradually to hare realized how small was the number of their opponents at this point. After they had strength. ened their right flauk by the ertire 3rd Corps (Le Boeuf) and Grenier's division of the 4 th Corps, these troops were put in motion for an enrelofing advance against the 'l'ronrille copses.

Aga:nst such a superior force the wood could not be permanentls held. A'ter the troops of the Xth Army Corps had shot away their last cartrilge, they had to relinquish the edge of the wood. Step by step they disputed the adrance of the eneny pressing after them. Hu succeded, uerertheless, about 3 o'closk. in getting in to the plantations in rear of the position of the 2tth Regiment and our 2 nd battalion.

Naturally the maintenance of the position in front of the wood wes no longer possible. As the left flank of the battalion was completely exposed, and the flanking fire was soon uubearable, they had to make up their minds to retire unless thes wished to be cut off. The movenient was carried out from the left tlank, in the direction of the hollow, and along this to the sonthenst corner of the Tronville copses, with marvellous cooluess, T'he enciny was kept at a respectful distance by constant halts, and the delivery of effectirc rapid fire.

- Still it was impossible to prevent eight of the men, of whom niost, however, were, wounded, falling into the liands of tho enemy during the retreat through the wood. Unbappily, also, tho other losses of the companies during this dangerous retirement were considerable.

After the companies, laving debouched from the wood, reached the road east of 'I'ronville, the battalion Commander, himself slightly" wounded, assombled the battalion on the same ridge from which it had commenced its adrance in the forenoon.

The battalion set to work : to occups these heights against the enemy, who was pressing on, and to rener the light. Our artillers, 
howerer, by its heroic behavionr, succecded in stopping the encmy in the Tronvillo copses. It was owing to its assistance that tho French only gained ground reres slowly, and did not reach the road.

It would not certainly have been possible to oppose for long such greatly superior forces. Already the shells of the eneruy's batteries, which had come into action to one side of the 'Tronrille copses, were falling in Tronville, when the hends of the 20th Infantry Division entered the field of battle at this point, and, by their instantaneous action, put an end to the adrance of the French.

The men of the and battalion, thoronghly exhansted after their glorious engagement with overwhelming superior forces, had to remain in the reserve position until further orders.

During the few hours occupied in the fight, the three companics bad lost in killed and wounded 12 Officers, 15 non-commissioned oflicers, and 123 privates.

Let th now turn again to the right flank of our fighting line, whero were the other portions of onr regiment.

The 1lth company was on the extreme right flank, separnted from the other companies of the battalion. To the left the poplar wood had just fallen into our hands; on the right the hurrahs conld bo lieard of the 35th, Tho, in concert with detachments of the 5th Division, land taken Flarigny. On both flanks the enemy was falling back in clisorder.

The 11th company was moring with a company of the 35th north of Flavigny, along the hollow towards the rond. The heights were just reached as French cuirassiers galloped ap to attack some troops belonging to our 5 th Dirision on the Flavigny plateau.

A few moments before, on the first signs of an impending caralry attack being noticed, through the adrance of single horsemen from Rezonville, the company Commander had hurrjed forward his company to the hedge of a bigh-lying feld, from which the wholo plateau could be commanded.

This short forward morement was now rewarded. The company was able from hero to direct its rapid fire on the right flank of the cuirassiers'.

In spite of the losses in men and horses which the cavalry suffered in galloping past, the attack was carried out with praiserrorthy bravery. It failed, primarily, owing to the coolness of the 52nd, who allowed the enemy to apronch to 300 paces in order then to receive him with a murderous rapid fire.

From the position occupied by the Ilth company, tho cuirassiers were secn to go back in confusion towards Rezonrille, too far off to be reached again by our needle-guns. The attack cost the cuirassiers 22 Officers, $205 \mathrm{men}$, and 243 horses.

The battalion Commander now ordered the 1lth company to join the regiment, by adrancing to the road. The company Commander led tho company, which was exposed to fresh losses, castriards, past the poplar wood, up to the road, and took up a position there on the right, near tho lst compans; with which the regiment Commander was at that moment.

roL. IXIF. 
In the lst battalion, in the meantine, owing to the great losses it had suffered in attacking the line of the road and the stationary. fire action that ensued, the rearraugement of the sereral commands, within the companies, was argently required.

The wiole of the Officers belonging to the three companies were now either dead or wonnded. Of all the Oficers of the battalion, ouly two Ijieutenants wero effectire, though both were wounded. 'liey assumed tho command of the lst and 2nd companies respec. tirely; the company sergeant-major was placed in command of the Ath company.

The battalion Commander was not actually wounded, though the buttons at the back of his tunic had been cut off by a bullet, which causcd a contusion.

On the left of the Ist battalion, first the 12th compans, and then the loth company, sncceded in making good their footing on the other side of the road. Adrancing in a mendow bottom, surrounded by poplars, both had pushed forward to a fold of the ground in the direction of the roal, from which an effective firo could be delivered ou the enemy's lines. 'J he 10th company had the good fortune to approach a battery of the enemy so unexpectedly that, surprised by the rapid fire of our Grenadiers at a few hundred paces, it withdrew rapidly, lenving behind an unlimbered gun. To reach the gun im. mediately under the cnemy's fire, was not practicable, notwithstand. ing all the efforts of the brave Gienadiers. I'Lis was effected later, during a pause in the fight.

In this adrance the Captain and a Second Licutenant of the 10th company were wounded.' Ono Second Licutenant had been killed carlier, and also a licuteunat of the 9th company, the Captain of which was wounded.

The greater portion of the 9th company, under the command of a Sccoud Lieutenant, was on the left flank of the fusilier battalina; ono zug, under a Second Lieutenant, had pushed forward still further to the lRoman road, and had been posted since early in the afternoon north of the road at a small clump of poplars, mixed up with portions of its own reginent as well as the 6.4 th and 91 st Regiments. The greater portion also of the 3rd company took part in the further fighting at this spot. It consisted of the sth and the rifle zug, which had been assenbled by the company Commander after the advauce described abore, and leel forward to the road at this point. He was sererely wounded by two bullets, and the command was assumed by a Isicutenant. $A$ Second Lientenant was posted with the 6 tin zug, further south, on the road in action; he had been separated from the rest of the company during the adrance.

'The other comprnies, also of the lst battalion, after a sanguinary struggle, pushing forward individual züge, had succecded in crossingr the road and occupsing the long fold of ground beyond it. From time to time masses of the euemy attempted to advance against it. 'The rapid fire of our lincs, and still moro the necurate firo of our batteries, prevented these adrances from succecding. Soon the position was permanently occupied. 
The firc, which had at first been directed at interrals with the greatest intensity ngainst our positions, gradually diminished. About 2 o'clock that of the infantry ccased altogether. Everyono drew his breath ! Bui it was only the calm before the sturm. Before long the fire was taken up again by the enemy on the north with increased energy. l'resh batteries came into action on the Roman road, and the battlo was soon in full swing again on this flank.

Things also became moro lirely in the front of our companies engaged cast of Vionville. IIere also tho enemy brought up fresle troops, and sent them forward to make a new adrance against the weak bodies of troops opposite to them.

The batteries brought into action on tho heights north-west of Rerouville to prepare this attack fired shrapnel and shell on the position. The rattle also of mitritilleuses could angain be heard.

Yet our rillemen held their ground bravely, supported by the artillery, which had come into action close to the infantry. The sitnation began to be critical. The troops had become extremely exhausted after the hour's fight in the hot Augast sun. And it was still little past two o'clock! Not a gun or a battalion remained in reserve, and fresh inasses of the enemy continued to assemble against oni position.

In this situation it became necessary for the cavalry to sacrifice itself.

Von Bredow's caralry brigade, consisting of the 7th Cuirassicr Reginent and the 16th Uhlan Regiment, undertook its self-sacrificing death ride before our ejes, passing north of the battle-field, and rodo victorious up to the last French reserves. Here the two regiments, attacked on all sides by French cavalry masses, were forced to turn back. The enems's artillery and infantry line had again to bo ridden through on breathless horses, pursued by the French horsemen. The remains of the binve cavalry fell back hurriedly on our right flank, in tho direction of Flavigny:.

Under the powerful impression of this spectrele, the fight seemed for the moment to hare ccased absolntely.. Everyone watched the wild cavalry chase with breathless interest.'

The two caralry regiments had, indeed, suffered regrettable losses; but their blood had not been shed in rain. The bold attack had so confused the euciny, that the advance prepared from Rezonrille was never carricl out. Our companies, indecd, assisted by tho confusion which the bold caralry attack caused at lirst, succeeded in posting themselves, still further forward, and gained a farourable position against the lowan rond.

This position was hold, when, after a short time, the moment described above supervened, and the two new Army Corps attacked onr extreme left thank from Bruville and St. Marcel, and forced tho infantry fighting on the left, at the 'Ironrille plantations, to go back.

The left wing ras now in the air, and the situation became very

1 Gencral v. I3redow, among the last to retreat, ras sared from a pursuing Freach Olicer by a musketcer of the reginent.-ED. 
dangerous. But, happily, no further serious fighting occurred. The enemy appeared to be exhausted. The infantry fire becamo more and moro silent. Only the artillery fire on both sides was continued, becoming at one time heavier, and at another less intense.

$\Delta$ fter the 2.4th Regiment had moved off, the 64th Regiment, posted in our positions, received the order to assemble at Vionville. The 12th Brigado was to form a reserve there, ready for all eventunlities.

The battalion Commander, viewing the marching away of the 6.1th Regiment as indienting a general assembly, went with the 11th coinpany in a southerly direction across the road to the poplar wood, with a view to assembling the fusilicr battalion there.

After he had picked up tho 9th company he led the two companies back to the heights south-rest of Vionville. On the way he picked np seattered men belonging to all the companies. Ho took up his position at the cemetery.

Tho interior of the penceful spot was filled with dying and wounded men, amongst them 20 Officers of the 20th Regiment, who were being attended to here by our surgeons. Many a shot still reached the spot.

The 10th and 12th companies received the order to join the battalion at Vionville. But the existing situation did not allow these companies to give up their position. The battalion Commander was informed of this, when his order was reccired and his sanction obtained for the companies to remain where they were.

South of the road, on a lerel with the Gorze road, two batteries were still posted in nu important advaneed position.' For the protection of these batteries there were at hand, besides detachments of the ¿5̄th Regiment, now only our two fusilier companies, and the lst, 2nd, and 4th companies. The battalion Commander placed one zug from each of his three conpanies in the adranced line, and pushed forward the rest of the 1st company, in one body, to the left; the supports of the 2nd and 4 th companies were somewhat retired to the vicinity of the road, so as to be withdrawn. as far as immediate conditions would allow, from the ground where the enemy's shells were falling.

Thus, these companies were the only troops which, tired to death nfter seven hours' fighting in the excessirc hent, held the French Gth Corps in check between Tionville aud Rezonville during the later hours of the afternoon.

About 4 o'clock P.sr. Prince Frederick Charles appeared on the battle-field. His Royal Highness had first receired the report at Pont-i-Alousson at 2 o'clock, that the fight about Vionville had assumed greater dimensions. After covering, as rapidly as possible, the intervening 3 miles (German), he now arrired on the right flank of the 5th Division. From here he took orer the further condnct of the fight, which now became more and nore extended on both flanks owing to the appearance of fresh German troops.

The 19th Division also had now arrived at 'I'ronville ant exactly the right time to mect the 4th French Corps, which threatened to turn our 1 About the point marked " $d$ " on the sketch.-ED. 
Ieft flank again from Brjuillc. The movement was stopped by tho 3Sth Brigade and the two cavalry brigades.

It was now 7 o'clock.

On the right flank, also, reinforeements-from the VIIIth and IXth Arms Corps-had gradually come up and given fresh impetus to the Gight by their inmediate participation in it.

Prince Frederick Charles decided to make one last ndrance against the enemy's centre at Rezonville shortly before dark. Although, owing to the extreme cxhaustion of the troops, an important tactical result was not to be expected, yet the enemy could be shown what conld be achiered by Prussian tenacity.

'lice order to advance reached the fusilier battalion Commander sonth of Vionville, where, as we have seen, he had assembled a portion of his battalion. Ho mored off at once with both the coinpimies, and marched south of the village as far as the poplar wood, and thence wheeling to the left up to the battcries on the road. Here the 10th and 12th companies joincel the battalion, which was now r'ennited, though considerably diminished in strength.

As suon as tho lst battalion Commander receired notice of tho task uudertaken by the fusiliers, he was delighted to join them with the remnant of his battalion. It was only a small lody, of scarcely more than 200 exhausted men, he was able to dispose of. Animated, however, by unlimited trust in their leader, they nll followed the order for a fresh advance-full of confidence. The advance was now niade across the road, with the left shoulder forward, directly on tho enemy's position. The 9th and 10th companies formed the first liue with tho rifle zïge extended; the 11th and 12th companies followed behind; the lst battalion was on the left flank.

The din of the day hnd been replaced by stillness; only here and there it was broken by tho dull boom of artillery, or tho sharp report of a rolley far on the enstern horizon.

The crest of the heights had now been.approached within about 500 paces. Suddenly nasses of caralry were seen to emerge from the enemy's position. "Ilie down!" was shouted by the Officers, in the expectation of being attacked at once by the caralry. Instead of this, the next moment the caralry wheeled outwards and unmasked the enemy's infantry position. At 100 points the musketry firo broke out at the saine moment, and a shower of bullets whizzed through tl:e air, happily too high to cause us serious loss. Only 9 men were hit; the fusilier battalion Commander had his second horso shot under him.

'The fire was now taken up on our side, and a brief fire action eusued. It liad already become dusky. $\Lambda$ dark mass appronched tho 1st battalion on its left flank. Wrergone observed it with brenthless expectation. Suddenly the cry arose: "Hostile cavalry!" The 11th and 12th companies whecled up, and, together with the lst battalion, opened a rapid fire that foreed the cavalry to turn about quickly. At this moment our Zieten Hussar Regiment came up from the rear. Greeted with loud shouts by our regiment, it rode through the infantry position and followed the enemy's caralrs. The tire of the 
infantry in front of us, on tho heights, broke out again with renewed intensity. The hussars had ridden up to the enemy's skirmishers, and were now between us and the enemy. By the efforts of the Officers, the fire from our side was soon stopped. In a few minutes it was shown how necessars this was, for tho Zicten Hussars galloped back on our lines aud assembled belind the infantry:

Onco again they rode forward to attack. But in the dusk any result could no longer be looked for:. It was 9 o'clock in the eren. ing, and had become so dark, that friend and foe could no longres be clistinguished from one another. The engagement gradually died away on both sides.

Deep silence prerailed in the ranks of the battalions as they now marched orer the battle-field to the village of Vionville.

During more than eighteen hours no one had rested.: For twelve lours the troops had been hotly engaged. Their last powers were used up.

After the men had had some rest at Vionrille, and had been some. what refreshed by water, the lst battalion commenced its march back to Tronville; and bivouncked near the 20th Dirision. The fusilier battalion went into birouac on the heights south-west of Vionville. Fveryone stretched himself close by tho arms, and all were soon wrapt in deep slcep. The cxhaustion was so grent that only few succeeded in kecping awake sufficiently long to recall the impressions of the erentful das.

And set how much had happened between the forenoon hours, in which the battalions had first entered that plain, and the crening! Tho most sanguinary battle of the whole campiaign had been fouglit. 8 Officers, 14 non-commissioned officers, and $140 \mathrm{men}$ of the 20th Regiment lay dead on the battle-field; $3 \pm$ Officers, 52 non-commissioned officers, and 481 men were ronnded.

Tho regiment could say that it had done its duts, and contribated to the results of the day. And these results mere far moro important than the immedinte tactical conditions secmed to imply. The German troops had gained a great. strategical victory over an enemy more than double their number. The design of Marshal Bazaine to lead the Rhino Army to Verdun to join the Chalons Army had been frustrated. Without Vionville, Grarclotte would not hare been possible.

On the morning of the 17th August the men were cariy afoot, awakened by the keen air, and collected in groups round the birouse fires. The battalions of the regiment wero ordered to assemble at. the Vionville cemetery.

Soon the regimental wagons arrired in the birouac. Tho men had had nothing to eat, except coffece and some bread, for nearly forty-eight hours; their joy, therefore, at the arrival of tho prorisions was accounted for. The wine which the regiment Commander had requisitioned from the rillago of Onville the day. before was reccived from the company wagons with special satisfaction.'

1 It may be renembered that the lnapsacks had been taken off and left behind near Tronville. When these were recorcred they were found rited of their contente. The surgeous had ordered them to be opened, aud the linen in then to be 
The companies bad, later, to be re-formed. Seren out of the twelpe had lost their Commanders, cither by death or wounds. The command of three of these was taken by First Lientenants, that of the remaining four by Second Lieutenants. 'The Adjutants of the lst and 2nd battalions liad to be replaced.

The dead were- buried in the evening at a spot close to the poplar wood.

Whereas, on the morning of the 17 th, it was apprehended that the cnems would emplos his grent supcriority in a renewed attempt to break through, the reports of the cavalry soon aunounced that the French Arony was falling back on Metz.

As early as the forenoon of that dar, it mas decided to attack it on the 18th. During the course of the day five Army Corps of the End Arms, and two Arms Corps of the lst Army, were concentrated in front of the cnemy's position.

The regiment had receired the order to be ready to mareh at 5 A.w. Abont 8 o'clock it was ordered to cook, and to march at micl-das.

About 1 o'clock r.js. it moved oft. The dirision marelied in rendezvous formation in a northerly direction.

The corps, howerer, did not take any actire part in the battle, and at night the occupation of Verneville was specially allotted to the 1lth Brigade.

The list battalion was to occupy the village itsclf; the other two battalions and the 35th Reriment teok up a position in reserve behind the village. The rest of the division eccupied a position southeast of Terneville, with the front towards Malmaison.

While the regiment was settling down in tho large divisional livoune at Vernerille, the order was received for it to mareh back to Doncourt to cover the hendquarters, and biroune there. The distance was not very great, but the night march appenred interminable. .... Between 1 and 2 o'clock in the morning the regiment reached Doncourt, and bivonncked without wood or straw. Requisitions could not be mado in the village, for it was full of wounded, whom it was undoeirable to disturb at that hour of the night.

$\therefore$ The three battles on the 14th, 16th, and 18th August had for their effect the shutting up of Jiarshal Bazaine and his Army within the walls of Metz. The next task to be prorided for by the headquarters wins the invesiment of the fortress, perhaps to besiege it and to prevent any attempt of the Metz Army to force its way out.

- On the rnorning of the 19th $A$ ugnst the necessars order was issued to the 1st and Lid Armies. 'l'he lst Army and the 3rd Reserve Division, the IInd, IIIrd, IXth, and Xth Corps were to be emploged in tho investment.

The dispositions for giving effect to this order were arranged in tho course of the 20th, and were in part carried out the same das. On the left bank of the Moselle, where attempts to break out were most likely to tako place, a continued entrenched line was to be established. On the right flank of this position the VIIth Corps, with the VIIIth takce for binding up rounds. A sinilar instince occurred two dass later with the Brd Reginent in the Manco Valley.-K.D. 
Corps on its left, was to nccupy the ground as far as Moscow, the IInd Corps that between MIoscow and the road from St. Privat to Woippy, and lastly the Xth Corps the valley of tho MLoselle below Aretz.

'Ihe IIIrd Corps was directed to occupy hutments in the ricinity of Caulre farm, the IXth Corps abont St. Ail. 'The former was to act as a reserve to the right wing, the lațter to the left wing of tho line of inrestment.

At mid-day the regiment received the order to cook as quickly as possible, as it was to march in the course of the afternoon to Caulre farm.

At 6 p.Jr. the regiment left its birouac at Doncourt, and nfter a short march birouucbed again, north-west of St. Mircel. The 6th Division took position leere on the left flank of the corps.

After arriving at tho spot named, at 7.30 p.y., a general cudearour was obserred to make the birouac as comfortable as possible, for a considerable stay licre was not improbable. In the absence of straw, attention was given to the coustruction of huts made of boughs. The aspect of the wenther scemed to warn us to make their coustruction as solid as possible. While still busied in making the huts there was a heary storn with hail; but the rain was welconie. The longcoutinued heat laid become by degrees unbearable. It was huped also that the want of water, which was severely felt, might be mitigated by the rain. In contrast to the extremo lieat by day, the moruings and evenings, and still more the nights, were of ten sensibly cold. This und the waut of water were the chief causes that led to the condition of the troops as regards henlth not being a farourable one. Belongiug to the regiment there were, exclusive of wounded, 9 non-commissioned officers, 1 musician, and 115 men sick in hospital.

In order to fill the racancies amongst the Offecrs of the regiments in the 10th Infantry Brigade, Officers of the 20th and 35th had to be detached to them. ${ }^{2}$ From the 20th Regiment eight 2nd Lieutenants were detached to the 12th Reginent. IIost of these Officers assumed the command of companies which had no Oflicers and few nen-com. missioned officers. One-year Volunteers, in many cases, took over the duty of sergeant-major.

The proportion of Offecrs in the regiment was by this measure reduced to one per company, besides the company leader, inclnsive of the vice-sergeant-major and the Portepeefibnrich.

Definite orders had been given from Arny Corps Headquarters respecting the supply of provisions. Independent requisitions were only to be mado quite exceptionally by the troops, and then only under the authority of the regiment Commnnder. As a rule, all provisions were to be drawn from the stores of the division, which were to bo supplied under requisitions by the Intendance officials in the neigh bourhood of Metz.

1 The 10th Brigade belonged to the other division of the corps. The 12th Regiment hat lost 16 Oflicers, the 52nd had lost 50, hilled and wounded. Tro of the 20th OEcers detached to the 12th bad themselres been rounded in the battle. -ED. 
Generally speaking, at this time there ras no lack in tho quotntity of the supplies. Ifive cattle were arailable in largo numbers; but the bread failed almost entirely and also spirits. Both were painfully miseed; the latter especially, owing to prevalence now of rain and to tho cold nights.

On the 23rd Augast the line of investment was drawn closer round Metz, which necessitated the morement of the IIIrd Corps. The new birouac of the regiment was west of Verneville, where hats were again constructed.

On the 25th Augast the following was the strength of the regiment:- Ist battalion, 693; 2nd battalion, 815 ; fusilier battalion, 685 ; total 2,198 men.

On the following day, tho 25th August, tho companies lad just retarned from drill and were busy cooking, when suddenly the camp was alarmed. The outposts had reported the adrance of the French. In storm and rain, mixed with hail, the division marched out to a reserve position at tho villnge of Amanvillers. But nbout 2 o'clock, after remaining there for an hour, it marched back. On reaching the bironac it was found that tho storn and rain had played haroc with tho huts, and seriously weakened the soup left in the kettles. An extra zation was issued as a specinl case.

On tho 27 th the regiment received a great and joyful surpriso in the receipt of the order to march at 10 A.s1.; its destination was rumoured to be Paris. The march was by Jouaville on Conflans, and the regiment was contoned at Wareq and Etain.

On the 28th tho march was resumed early, and the dirision had just passed MIorgemoulin when the order was received to halt. The troops stood for more than an hour in the streaming rain, until the return of the regimental Adjutant, who then brought the order for the return march to MIetz.

March-quarters were arranged for tho regiment for tho night at Morgemoulin and other localities in its immediate vicinity.

Tho reason for this march was that on the previous day intelligence had, reached Prince Frederick at Bar-le-Duc, that tho Army of Chalons had marched off in a northerly direction in order to assist Marshal Bazaine. In consequence of this, the order was given for two Army Corps of the investing army to march on Dauviliers, so as to be ready to attack Narshal MacMahon's Army from thence on the day following.

As on the 28th the situation had been so far cleared as to make it evident that the morements of Macilahon on the Heuse coald be.held in check by the IIIrd and the Meuse Army, the forward morement of the two detached Army Corps was at first temporarily postponed, and later on they were again placed at the complete disposal of the Commander of the Mletz investing force.

29th Angust was to have been a rest day after the fatigues and the constant exposure to rain of the preceding days. But at 4 P.X. tho cantonments were alarmed, and the retarn march to MSetz commenced by Etain. It was greatly delayed in the most fatiguing manner by the train and other vehicles, which on a rerersal of the direction of the 
march, were partly in front of the troops. The now march-quartcrs, at Jeandelize and-Boncourt, were not reached until 11 r.M. Tle regiment remained in them the $30 \mathrm{th}$, and it was intended it should remain there on the 3lst also; but shortly before 1 o'elock the whole of the cantonments were alarmed. The division marched in the directioin of St. Prirat la Montagne, and assembled at the enstem eutrance of Jonaville about 4 o'clock, where it rras halted. It was movel forward at 6.30 p.s. as far as the Batilly-Verneville road, where the troops birouncked, the regiment with the advanced guard, its left flauk resting on Batilly:

After the quarters it had occupied during the last few dass, the rergincnt experienced again the most uncomfortable aspect of the bivounc. There was no straw, and only wood in insnfticient quantities. The nieght was really cold, and the baggrage train had been left behind at the cantonments. II ungry and cold, the men lay down in their half-dricd clothes on tho damy ground, to seck in slcep oblivion of the uncomfortable-situation. Irappy were those who suceceded in sccuring a place in the proximity of a warm firc.

It was no wonder, considering this anything but healthy.life, that the sanitary condition grew worse from day to daj, notwitustandiug the endearonrs of the superior Officers to neutralize as far as possible theso harmful influences. Amongst other things the regulated issue of a small mation of spirits was rendered possible by the extensire requisition of brandy and arrack. It was also dirceted by an Army Coups order that an extra ration of flour was to be issued daily, to facilitate the preparation by the men of an evening soup, as the continued consumption of fresh-killed meit was found to be detrimental.

1st September.-The morning was bright and sunny, and the old humour of the men began to return... Thes could not get orer the disappointment experienced through the hoped-for march to Paris not. haviug cone off. "Punce Frederick Charles loves us a great dcal too much," said one; "how could we ever-hase thonght he would permit his IIIrd drny Corps to go away from lere?" Auother suggested that it was in the interests of maintaining the purity of morals in the IIIrd'Army Corps that it yas not to be bronght into contact with the Babel on the Seiuc.

On this day the battle of Noisserille was fought on the right lank of the Mloselle. At $8.30 \cdot$ A.S. the 6th Division was morcd to Marengo farm, but was not engaged. It subsequently occupied the section of the first line of investment, extending from Saulny: to Chatel, relieving the VIIIth Corps, mored to the south front.

'Ille 1lth Brigade took over the actual outpost position, with the -20th Regriment on the left and the 35th on the right: The 12th Brigade bi rouncked at Marengo in the 2nd line.

The entire extent of the outpost line occupied by the regiment was more than 3,060 paces; and the following was the distribution of the troops :-

!. 5th company : 1 zog, pushed forvard as a picquet ; 2 zügo as sapport at the Saulny Bath-house, communication - with the 35 th Regiment. - 
Gth company: $1 \mathrm{zng}$ as a picquet between tho bath-house and the brick-kiln; the two others as support in the 2 nd line.

7 th company: 1 züge in the brick-kiln, the remainder behind tho barricade on the road.

Sth company : in the alarm-house, as support to the Fth company at the barricade.

9 th compang: 1 zug as picquet belind the abattis north of the road; 2 zä̈ge belsind in support.

12th company: 1 picquet to tho left of the 9th company, with support behind, conmunicating with the Xth Army Corps.

lst Lnttalion: in tho alarm-houses of Saulny.

10 th and 11th companies: 1 . nilo behiud on the rond to St. Prirat as $\Omega$ general reserve.

In Officer's post of obscrvation was established on a clear spot limbly situated north of Saulny.. Two Officers were detacied there, oue of whom belonged to the reginent. During the day the whole of the ground in adrance was to be continuonsly observed, and ay inportant movement of the cnemy reportel at once to the Commander of the outposts. To facilitate this, mounted orderlics were attached to all the observatories established on the elerated points around Aretz.

Shortly beforo niglatfall the outposts at Saulny wero reinforced, and parties wero kent forward in different directions to listen. Fires were not permitted during the night, because the French at once opened fire on them. On this day, when the regiment had only completed the occupation of its position as night began to fall, this precaution, though necessitated by the circumstances, made itself rery unpleasantly felt by our men. Since the coffee at the Batilly bivouac, thes had had nothing, and but few carried any provisions in their harersacks.

From 3 a.x. until daylight all the posts and piequets were under arms.

3rd September:-Consequent upon the arriral of the 5th Division from Mlaizières, a change was made in the disposition's of the ontposts. From that day the section of gronnd was divided between the two brigades. The left portion, hitherto occupied by the 20 th Regiment, was allotted to 12th Brigade; tho right portion to the 11th Brigade. The regiments of the brigades changed places in such a manner that one was in the advanced line, while the nther was placed behind in reserve. In consequence of this arrangement the $20 \mathrm{th}$ Regiment was withdrawn to Amansillers, where it was bivouacked and extempore shelter constructed.

7th September.-It relieved the 35th Regiment on the outpost line. The followiug were tho dispositions:-Right: the fusilier battalion, 1 company as picquet at the Chatel wood, behiud an abattis, with 2 advanced non-commissioned posts in the most adranced shelter trenches. Communication with the IXth Army Corps. 1 company in shelter trenches, on the southern border of tho Vignenlles wood; a noncommissioned otfecr's post, about 300 paces forward, on the Amanvillers.Woippy road; 2 companies in support, in front of St. Vincent. Centre: 2nd battalion, 1 company in St. Vincent, 1 in St. Maurice, 
2 as support west of the redonbt (of the battery placed in the second line of defenec). -I Left: 1st battalion, 1 company in the Vjgneuelle wood, at the abattis, in prolongation of the line of shelter trench leading to the brick kiln from Saulny. Communication mith the 12th Brigade: 1 company to its right, behind nu abattis, which blocked the bollow running through the Tignuelles wood in south-casterly direction; 2 companies in support in front of $\mathrm{St}$. Maurice.

The regiment, therefore, was placed in three lines, one behind the other. In the first line were 4 -companies as picquets, which had pushed forward non-commissioned oflicers' posts. In the second liue were three half.battalions as supports. In the third line 2 companies for the occupation of the two farms.

The regiment Commander commanded the outposts, having at his disposition the battery and the zug of caralry attached to the outposts.

loth Septenber:-The dispositions were slightly modified by the withdrawal by order of the dirision Commander of the centre support, nnd the occupation of St. Vincent and St. Maurice, cach with two companies.

On the 10th September an Army Corps order dirceted that regiments were not in fulure to be kept for moro than forty-eight lour together on outpost duty.

13th September.-A draft of 5 Officers, 9 nou-commissioned officers, and 95 men arrived from the Ersatz battalion.

The marching out strength of the regiment on the 14th Septembor was tho following :-

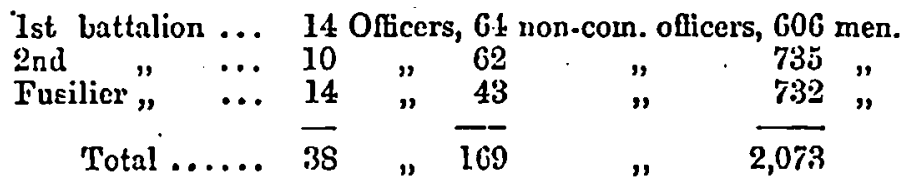

Fyom this dato up to tho 27th October, when the fortress and garrison of Metz capitulated after seventy days' investment, the morements of the 20 th Regiment call for no special notice.

\section{MLarch from the MLoselle to the Loire.}

After the fall of MIetz, the 2nd Army, with the exception of the Ind Army Corps, which was ordered to reinforce the Army of investment round Paris, was directed on the middle Loire, to support the weak German forces already detached there from before Paris.

30th October.-The 20th Kegiment, which was occupying Plappe. ville fort, received the order to march. It moved forward the same day.

3ist October.-At Waville the regiment ras rejoined by a detachment of conralescents, about 100 in number, sent from the Ersatz battalion. The strength of the sereral battalions was now as follows:- 


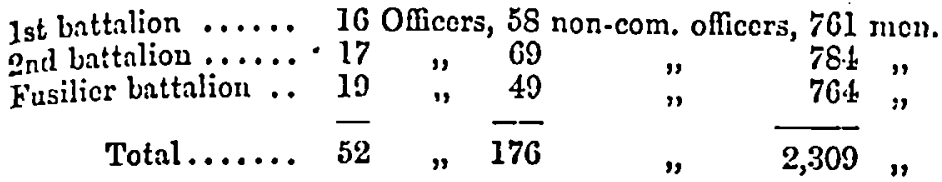

2nd Norember.-The greater part of the 6th Division cntered the Departnicnt of the Meuse. The 1st battalion reached Boncourt; tho Ind battalion, St. Julien, and the fusilier battalion Commercy, and remained cantoned in these places during the 3rd Novenber, which was a rest day. But there was plenty to do. Arrangements had to be minde for putting into effect an order received from headguarters sllowing of the attachment of two wagons to each battalion. Of the surplus tenms, those of which the material was good were to be formed into a park carriage column, and the rest dismissed.

Further orders were also received regarding the manner of marching, which was in future to bo by brigades or divisions, connection being maintained on the march between the trro dirisions. Strict injunctions were given that sick soldiers were on no nccount to be left belind during the marches, and that tho artillery and train columns were to take them np.

4th Norember.-The lst battalion reached Telaines, the Ind battalion Ligny, and tho fusilier lnttalion Nnncrois le Petit. 'This day's marcl was a long one again. 'The fow dajs' morching had been sufficient to improve the powers of the Brandenburgers, who had in some degree become unaccustomed to marching. There were hardly any footsore men. Mlore attention was now paid to the measures for security. In the lst and fusilier battalions, besides strong cantonment guards, alarm-honses were selected at the exits of the villages; the 2nd battalion sent forward picquets in the direction of Stainville. Besides these precantions patrols were sent out from the lst battalion to search the Yelaines wood, and from the 2nd battalion to the Ligny rood.

5 th Norember.-The Ist and fusilior battalions renched Saronnières-en.Perthois, and the 2nd battalion Narcy. During this day's march a formed adranced gnard was emplojed again. Fiom the last rendezrons the units separated to march independently to their sereral cantonments. As a rule the Quartermasters went in advanco to the cantonments from the general rendezrous. There was for the troops this disadvantage in the arrangement, that their coming was not known to the inhabitants sufficiently carls, and they had frequently, therefore, to wait a long time after their arrival before they could get a hot meal.

During the further adrance it frequently happened that singlo companies were detached. This was generally done with the object of obtaining better shelter, and often also to cover the larger bodies and staffs in rear.

Gth November.-The regiment marehed again closed up; but tho wagons followed their own battalions. Ono wagon was employed to carry the sick, the number of whom had again increased during the 
last two clays. It wis noticeable that those who fell sick were alnost entirely convalescents, who had rejoined with the.last draft from the Ersatz battalion. In the of inion of the medical Officers their strength had not been sufficiently re-established to support continuous fatigne. In the cases of some men who had been wounded, the wounds broke out again in consequence of the arduons marches. The Frsat\% battalion was, thereforc, notified from the regiment not in future to send back sick or wounded men before they had been quite re-estab. lished, aud their powers of endurance tested.

The regiment suffered inconvenient delny in crossing the Narne at Bienville, where all the streets were blocked by the train of the IXth Army Corps.

10th November.-The country through which the march lay was so poor that the villages in which the battalions were cantoned were unable to provide sulficient food for the men, and reconrse was had to the provision wagons. It rained almost all day, and was very cold.

Ilth Norember was to have been a rest day. But news was re. ceived from the headquarters at Versailles that the 1st Bararian Corps had been forced by superior forces to eracuate Orléaus, and that the enemy was adrancing on Paris. Haste was therefore necessais, and the 2 nd $\Lambda \mathrm{rm} 5$ was directed to continue its advince by forced marches. In consequence of this the Army was mored forward half a day's march in the afternoon of the same das. The lsi battalion reached Iontierames; the 2nd battalion Lusigny; the fusilier battalion Jlesnil St. P'ire.

The first snow fell during the night of tho 10th to the 11th Norem. ber, the precursor of the serere winter that followed. Daring these forced natrches the carriago of the men's packs on carts was permitted. The carts were requisitioned, and formed an inposing train behiud the advanced guard.

12th November.- The 2nd battalion receired the order direct from the division to adrauce to Troyes, and corcr the headquarters there.

The other bittalions moved again with the advanced gaard; tho lst batialion to St. Savine; the fusilier battalion to St. Martin.

$\Lambda t$ T'rojes traces begau to be seen of the newly organized resist. ance. In the town itself wero traces of entrenchments and barricades, showing that the original intention had been to defend it. Other bodies of troops lial also becu in contact with franc-tirenrs. Picquets were therefore placed on the left bank of the Seine, on all the main ronds leading in the direction of Némours.

'The stay in the manufacturing town was utilized by making considerable requisitions of woollen clothing and stockings.

November Ioth.-I Inalquarters arrived at Gens on the Yonne. Here, on the previous day, the lost and Telegraph Staff of tho IXth truy Corps had becn seired, and the post carts cunptied; and gencrally in Sens feeling was very much excited, so that armed resistance appeared possible.

On this account, the end battalion receired orders to march there carly in the noruing, accompanied by a squadron, to free the cap- 
tnred postal officials, and, after restoring order, to preparo ererything for the arrival of the troops behind.

Besides this, the.2nd battalion had another special duty to perform on the same day. On the previous night, an liussar of tho 16th II ussar keginent had been assaulted and robbed by the inhabitarnts of the village Pont-sur-Vanne. He had the pace of his horse to thank for lis life. Until the end of the enquiry into this, a zug of the 5th compans was left in the village. After the guilty persons had been identified, the punishment was carried ont the same afternoon by shooting two of the inhabitants and burning the farm.

16th Norember.-After nine consecutive days' marching, the dirision was given a day's rest.

17 th Norcmber. - The reginent moved, the 1st battalion to Villebéon, the 2nd to Isorrez-le-Boccage, and the fusilier battalion to Ia villeneure. 'The hospital cases were sent to Sens, where a conralescent company was left by tho division, a measure rendered necessary by the hostile attitude of the inhabitants and the absence of ćtappen troops.

19th November.-The Ist battalion reached Aulnas-la-Rivière; the ond battalion, Grangermont; and tho fusilicr battalion, $L a$ Neurille.

With a closer approach to the theatre of war, the measures for security became more and more extended. The most adrauced cantonments were now regularly secured by outpost positious. The noncommissioned officers to inark off the billets could no longer be despatched in frout from the last place of assembly, as had previously been done, but formed the head of the advancing troops. The occupation of localities, therefore, was now generally carried out without billets for lodging.

The signs of the enemy's proximity increased with each day's march. The roads were found broken up more and more frequently;, without cnusing, however, a real hindrance to tho advance, for the pioneers knew how to restoro them in the shortest possible time. When the ronds were found to be blocked on the enemy's side of the advancel cantonments, the civil anthorities were made to restore them under pain of considerable contributions. The work was generally duly carried out in an incredibly short time.

20th Norember.- Two companies of the fusilier battalion werc sent on carly before the advanced guard to occupy Pithivicrs. The 1st battalion reached Escrennes, the 2nd Frenay, and the fusilier battalion Pithiriers.

On the arriral of the lst battalion at Fscrennes, the Commauder of the regiment received in report that Santean was occupied by tho cuemy. From the wording of the report, it appeared that the eucmy was rot in strength. The lst and 2nd companies were therefore ordered to adrance and clear the place of the enemy. 'They had scarcely marched off when fresh reports arrived to the effect that Santerin was occupied by strong bodies of infantry, apparently tho outposts of tho Isoire Army, situated immediately behind them. The morement was therefore countermanded, and the two companies 
adranced as outposts towards Santenu, tho other two companies of the 1st battalion being placed in alarm-liouses.

The German troops bad re-established touch with the enemy, who were situated hardly further than $4 \frac{1}{3}$ miles from our cantonments. After twenty days' marching, the 2nd $\Lambda$ rmy was in the positions in which it would be able to fulfil its object of covering torards the south the Army investing Paris against the French Army of the Loire. The distance traversed was orer 237 miles.

2ind November.--The 6th Division was ordered to more to its right to make room for the 2 nd $\Lambda$ rmy to form up. After diuner had been coolied in the old quarters, the 11th Brigade assembled, at 3 r.s., south-west of Jouy, and from there took up the line of outjosts allotted to it by Atray-Crottes-Liphermean farm.

'The left flank of this line fell to the regiment's lot. On account of the close nature of the country, which in Beance, the gramary of linnce, is corered with rillages, farms, and groups of trees, the adoption of an ordinary outpost line was quite impractic. able. liecourse was had to positions of preparation, so arranged that strong masscs capable of resistance were cantoned in the first line, secured by inclividual piequets being pushed forward and by an active patrol service being maintained, both by day and night. Entire companies werc posted in alarm-houses on all the approaches leading towards the encuny.

The fusilicr battalion was in the most adranced line, with three companies in MIontigny and one company, with a zug of dragoons, in Bout-de-la-rille. 'I'wo outposts rere placed south of Montigny, and one south of Bout-de-la-ville. 'Ihree companies of the 2nd battalion, with the regimental Staff, were in immedinte support at $A$ tray; the bth company occupied Baudas, on the extreme right flank.

The whole of the lst battalion was in the sccond line at Izy (sce sketch 2).

23rd Norember.-The situation remained the same, except that the companies in support changed places with those on the outposts, and the regimental Staff changed their quarters to Baudas. The enemy had occupied the villages on the near side of the great Orléans wood. In front of the position occupied by the regiment, their presence was reported at Chilleurs-anx-Bois and Neurille.

2.tth Norember. - With a view to ascertain more clcarly tho posi. tion and strength of the Loire Army, xeconnaissances wero ordered along the whole extent of the line occupied by the 2nd Arms. The force emplosed for this purpose by the 6th Division consisted of * battalions (the 1st and fusilier battalions of the c0th Regiment, and 2 nd and 3rd battalions 35th Regiment), 2 squadrons, and 2 batterics, under the command of the Colonel of the 20th Regiment. Its adrance by 'I'cillaj-St. Benvit, torards the Orléans wood led to the engagement of Neuville-aux-Bois.

The order for the troops to asscmble at 5 A.s. north of Teillay-leChene was issned late on the previous night. Packs were to be left in the cantonment, and the ammunition carried in the harersacks.

It was quite dark when the troops were marehed to the place of 
assembly; the roads were very deep after the continuous rain of the preecding dass. No one knew what was the object of the movernent. The order receired to aroid all unnecessary noise and loud words of command led to the idea that the intention was to surprise the enenis. On arriring at the place of assembly, the object and general disposition to be adopted were explained to the Oficers.

At 5.30 the actual reconnoitring detachment, consisting of the fusilier battalion 20th Regriment, the 3rd battalion 35th Regiment, 6 ziige of dragoons, and the heary battery, marched off. The next colnmn remained at Teillay in reserre.

The IIth compans of the 20th aud tho Ilth company of the 35th Regiment formed the advanced guard, the command being given to the Officer commanding the latter, as be had been on outpost duty with his company opposite St. Germain, and thereforo knew tho ground.

The 9th, 10th, and 11th companies of the regiment and tho dragoons followed immediately in renr of tho adranced guard. Tho caralry had orders to more forward directly the farms situated in front were attacked, and getting in flank arid rear. of them, to take as many prisoners as possible of the retiring cuemy.

'The 9th, 10th, and 12th companies of the 35th IReginent and the batters formed the main body, and were to take up a sheltered position temporarily at Mauregard. 'The adrance of the advanced guard companies took place west of this place, the 11th company 20th Resiment on the left, the 11th company 35 th Regiment on the right. Each company had one zug extended; the other tro züge followed at about 50 paces distance in close order.

The expectation of surprising the enemy was disappointed. The places reported the provious night to be strongly occupied were found to have been eracuated. Wheeling to the left, the adrance ras continued in the direction of Neuville-nux-Bois.

The 9th and 12th companics followed tho 11th, in company columns at deploying interral. The 10th company received the order to maintain communication with the compans of the 35th Regiment, and to extend in the gap between it and the 11th company.

On npproaching tho ridge on which was situated the Moulin.de-laMotte, the enemy's adranced troops posted there opened fire on tho skirmishers as soon as they appeared on the open ground. $A$ further adrance could only be carried out at the expenso of serious losses. The Commander, therefore, ordered up the battery to fire on the ruill from a position south of MLauregard. After the artillery fire hat prodaced its effect, the position was assanlted, and the enemy driren back on Nearille.

From the Windmill ridge the ground slopes down gently to the little town of Neuville, distant 700 to 800 metres. The ground is generally flat, only in places corered with stone houses, outlying buildings of the town. On the ensterly side of it the Orléaus-Pithiriers Railway sweeps in a great curre in the general direction north-cast and south-rrest.

An inmediate adrance on the town would at this moment have rol. XIsis. 
probably been successful, for the enemy seemed to be still in the act of assembling, and now for the first timo hastened up to occapy various points of their line of defence. But the companies were so ont of breath that it was necessary to give them a moment's rest. Besides, the sapporting companies, retarded by the sticky clay, were not jet up.

In the meantime the battery was ordered up to the Winduill ridge, and opened fire from its position east of the mill on the cnceinte of the town. The enemy had ocenpied the border of the town, the issues from which were strongly barricaded, the houses situated on the front of attack, and a portion of the railway embankment.

When the battalion had assembled again the order was giren for a further advance. The 10th company and the 11th company of the 35th Regiment adranced on the zight of the St. Germain-Neurille road; tho 11th company on the left of it. The 9th and 12th companies followed in close order.

The embankment was successfully assaulted, though with considerable loss, owing to the adrance being orer open ground in clay soil under a heary fire. The euemy fell back into the town. The 1lth company, entirely extended in a skirmishing line, occupicd the embankment; behiud it wero the 9th and 12th companies, also protected in some degree by the embankment. The loth company was extended on its right, opposito to the northern border of the town, only scantily sheltered by the garden hedges. Two of its zügo were extended as shirmishers; the third was in support in closo order.

The firc only censed for the fow minutes during which the enemy was occupied in getting into their new positions. It then broke out agilin with renewed intensity at close range, not cxcceding 200 paces.

The enemy was dificult to get at; thes were corered by a fortified enceinte which had becn mado almost sccure from assault. A stationary fire action ensued, while the artillery from its position on the Windmill ridge endearoured to set fire to Neurille. In spite of the accurato fire it did not succed in doing this, as the buildings were massive and the roofs slated.

In the menatime, tho Commander received intelligenco from cavalry patrols sent round to the rear of the town, that strong infantry columns were visible there, and that all the farm buildings sitnated between the town and tho Orléans wood wero occapied by the enems.

In these circumstances, as the only object in rien; which was to force the enemy to deploy so as to observe his strength, had been attained, the order was given to retire slowly. It was now abont 8.30 o'clock. 'The retirement, over open and bad ground under the enemy's close fire, was carried out by the sereral lines occupying successive positions to cover the morement of the adranced line.

The reconnaissance actions engaged on the 24 th $N$ oreniber in front of the entire line occupied by the 2nd Army showed that the encm5 occupied with all three arms the line Cherills-Nenville-aux-BoisChilleurs-aux-Bois-Bellegarde. 
25th Norember.--Thio general distribution remained nnaltered, as from the reports received from the caralry and other news it was now bejond doubt that considerable and far superior forces of the enerny were situated about Orléans. Prince Frederick Charles determined to remain on the defensive until joined by the Dake of Mecklenburg's troops, which had been directed on Beaugency, and the arrival of which would nearly double the number of troops at his disposal.

On account of the close proximity of the enomy, the duties in cantonments, especially in those situated in the first line, becamo every day more arduous. Numerous precautionary measures made the outposts' duties more difficult. Amongst others, the positions of the several posts were frequently altered at night, so as to be more secure from the enterprises of the enemy.

Cavalry Officers' patrols went out early in the morning to the front to observe any changes in the occupation of localities. Special reconnaissances of the ground were made by infantry detachments under the command of Officers. Theso had particularly to obtain reliable information regarding the direction and condition of the existing communications. The maps of the neighbourhood in possession of the troops were very inaccurate; and urgently required correction. It was of the utmost importance to fix accurately the metalled roads, for the roads shown on tho maps had prored when used for concentration to be frequently impassable.

On the 28th November was fought the battle of Beaune-la-Rolande, in which the regiment took no part.

On the 29th the regiment went into cantonments at Boynes.

At this period the supply of the troops became again a matter of difficulty. The entiro district was completely exhausted, and an étappen lino with a regular service of supplies from the rear did not exist. The villages occupied, though generally willing, were not for the most part able to furnish anything, as they had been taxed to the uttermost by the prolonged stay of the army in this position. Indeed directions xrere given by the superior Officers not to take the last resources of the inhabitants, lest famine should ensue.

In order to ensure supplies in the event of a longer stay, committees were appointed to buy provisions of any description and at any price. The gold always brought to light much that conld never have been got at without it. Altogether, and especially in the regiment, tho want was not very great. The men learnt that thoy must depend on their own activity to supplement the irregular issues.

Ist and 2nd December.- The regiment remained in its cantonments at Boynes until the evening of the 2nd. On the afternoon of that day a telegram was received from headquarters at Versailles, to the effect that the situation demanded a general attack on tho Loiro Army, and the advance on Orléans. In preparation for carrying this out on the following day, Prince Frederick Charles assembled on the erening of the 2nd December the IIIrd Army Corps about Pithiviers, and the Xth Army Corps at Boynes and Beaune-la-Rolande.

Late in the evening the order for this concentration was received $3 \times 2$ 
by the regiment, which reached Pithiviers at il r.x. An Officer hid been sent on to arrange the billets, so that notwitustanding the late. ness of the hour there was no confusion in getting into quarters.

3rd December.-Tho forward movement undertaken by the whole force on this day led to a series of isolated engagements on the 3rd and 4th December, which, taken together, constituted what has been termed tho battle of Orléans. The 20th Regiment participated in the actions of Chilleurs-aux-Bois on the 3rd, and of Paumainbert on the 4th December.

\section{Engagement of Chilleurs-aux-Bois. . (Sez Sketch 2.)}

- About 6 o'clock on the morning of the 3rd December the regiment commenced its march to the place of assembly ordered for the division, on the Pithiviers-Orléans main road, north of Mlarcan-anx-Bois. The following was the strength of the several battalions:-

Regimental staff and 1st

battalion ..............

2nd battalion............ 1

Fusilier battalion ........ 13

15 Officers, 46 non-com. officers, $605 \mathrm{men}$. 12

Total........ $\overline{40} \quad, \quad \overline{150}$

61
43
150

633

$608 "$

$1,8.9$

The ground was frozen and corercd lightly with snow; a cutting, cold wind blew across the fields.

The 6th Division was concentrated across the Pithiviers.Chilleursnux-Eois rond, with the corps artillery behind it, and the 5th Dirision on its left. Officer's' patrols returuing reported Santeau, which was situated in front, to bo strongly occupied.

In accordance with the orders given by the Corps Commander, the 6th Dirision with the corps artiller'y commenced its adrance on La Brosse at 9.45 s.1.r. The 11th Brigade formed tho adranced guard, followed by the 12th Brigade as main bocis; tho divisional artillery mored between the two. The 20th Regiment followed tho 35th Reginent as second line. The deployment followed in crery respect the regulation pattern of a peace inanoenvre. 'The brigade adranced in column from the centre at full deploying distance until it reached the limit of the enemy's fire. North of La Brosse the companies in the first line were extended.

Owing to an unfortunate accident tho Commander of the 2nd battalion, whose leg was broken from a kick bj a led horse, had shortly afterwards to be replaced by the senior Captain.

$\Delta$ halt was made at the village of La Brosse. The Fusilier Regiment occupied the border of the village, the 20th Regiment was placed bebind it, sheltered as far as the open natare of the ground would allow. The artillery took ap a position from which to bombard the enemy's position. 'This led to a lively artillery action, which was shortly supported on onr side by thr, corps artillery coming into action on the right flank.

The lrench artillery fire caused little dnmage, some sliells burst 


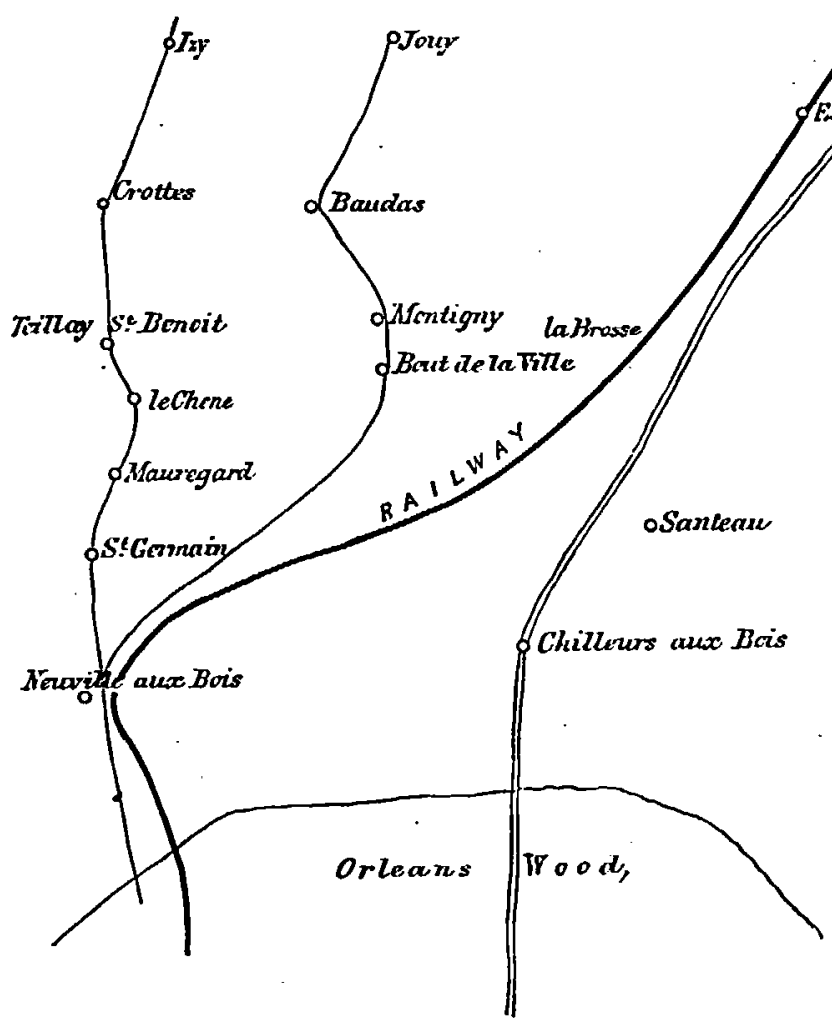

Scale, about two mites to an inch. 
in front of the battalions, some behind them, while a great number nerer burst at all, notwitbstanding the hard state of the ground. Their guns gradually ceased firing, and the infantry was also seriously shaken. A retrogrado movement began to be apparent at different points.

About noon, therefore, orders were given for a general adrance. The 11th Brigade, with the 20th Regiment in eccond line, advanced against the heights of Sauteau. The enemy, without a-waiting the attack, withdrew to Chilleurs-aux-Bois.

The encmy's batteries had already withdrawn to a position south of this place. The village itself was occupied strongly with infuntry. But our shirmishers were not to bo stopped in their forward movement, which was joined in by the artillery. A lively artillery action took placo ngain; but it was of short duintion. 'The enemy's guns were overwhelmed, and the 35th entered the village without serious opposition about 2 P.3. The enems disappeared into the Orléans wood.

$A$ long halt was made south of Chilleurs, so as to assemble the troops of the first line, and to rest the men after their fatiguing march throngh the heary ploughed fields. The caralry followed the enemy, and established the fact of his retirement into tl:o wood without rallying.

The weather had changed to heary snow, mixed with rain; bnt, notwithstauding this, and the lateness of the hour, the pursuit of the enemy was resumed at 4 o'clock. Both dirisions entered by different paths into tho thick wood. Beforo the main Orlénns road was reached the regiment had to force its way through the thick underwood. The main road, when reached, was found to be obstructed with 1 .enches, wire entanglements, pits, and erery kind of obstacle. Fvidences wero to be seen in every direction of a disorderly retreat. While other portions of the division wero still in the middlo of the wood, a heavy musketry and artillery fire saddenly broke ont in the direction of Neurille, which necessitated their forming up. The rest of the division, including our regiment, continued their march to Loury 4 or 5 .miles further south on the Orleans road; Loury was renched in the dark at abont 6 r.3.

The 35th Regiment furuished the outposts sonth of the village, and our 2nd battalion did so in the wood itself; the tro other battalious birouacked at the northern issue of the village.

It was bitterly cold, the men were drenched through, and, oring to the rapid adrance, the provision columns had not been able to como up. Some straw and damp wood from the village were the only aids to comfort arailable. 'The carefal men' who bad carried in their haversack gome coffee or a piece of bacon or erbswurst, prepared their warm meal, envied by many. Tho majority had to go without. During the night the bivouac was alarmed by firing at the outposts, bullets falling thickly in the birouac, and the 3rd company turned ont to support the outposts. 


\section{Action of Taumainbert. ${ }^{2}$}

4th December.-The order was received for a further advance on Orléans; the 6th Division to march by the main road, and the 5th Division by the Vennecy road, to its left. 'The baggage, for the protection of which on the prerious day the 9th company had been left at Pithiriers, was ordered forward to Isoury, there to await orders.

At 8.30 A.Jr. the 11th Brigade assembled south of Loury, and, shortly afterwards, commenced its forward movement.

The 1st battalion 35th Regiment led the advance, followed by the $10 \mathrm{th}, 11 \mathrm{th}$, and 12th companies of our fusilier battalion, the 5th heary battery and the 1 st and 2nd battalions of the regiment. Tho 2nd and 3rd battalions 35th Regiment protected the right flank, marching by Rebréchien and Marigny.

On approaching the outskirts of Orléans, the village of Vaumainbert was found to be strongly fortified, and the caralry advanced gand was receired with a hot fire.

Most of the farms situnted on both sides of tho road leading throngh tho villago were prepared for defence, and connected by entrenchments. The rincyards to one side and behind the rillage, as well to the south of the ridge as far as the main road, were furnished with trenches. The defence had been entrusted to the marino infantry, the best troops of the Republican Army.

The Ist battalion 35th Regiment extended for the attack, and, notwithstanding a determined resistance on tho part of the enems, penetrated the village. But a further advance was impossible without veinforcement.

The brigado Commander, thercfore, ordered the 1st and 2nd battalions, 20th Regiment, to advance right and left of the road against the enemy's flanks. It was now about 2 P.x. The Ist battalion advanced with the 2nd and 4th companies to the right of the road, and the lst and Srd to its left. The movements of the former two companies will be first described.

The 2nd company, covered by a strong firing line formed by the 4th zag, turned a half to the right and moved forward towards the vine-corered hill in front. Pressing forward rapidly against a farm, situated on tho northern edge of the rillage, it gained possession of this without a check. The enemy withdrew through the gardens to the hill, and thus enabled the compang, which now extended, also, its rifle 2 ag on its right flauk, and took position with the 3rd zug in close order at a decp-cut ditch, to occupy the farm buildings, and bring from thence an effective fire to bear on the enemy.

On the further side of the garden a pretty broad ditch, filled with water, brought the adrance temporarily to a standstill. An attempt

1. Taumainbert is a rillage about 2 miles N.E. of Orleans on the Pithiricrs Rosd. No plan, except on a rery largo ecale, rould render the details of the attack clear, and this is not forthcoming. The account is, howerer, ingerted, as it mag be useful to any Oflicer who maj at anj time be studying this part of the cempaign on the ground.-ED. 
to jump over this obstacle fniled. The Lieutenant in command of the company was sererely wounded in reconnoitring for a way to adrance.

To the right of the riflemen of the 2nd company was situated a larger farm which tho enemy still occupied strongly. The 4th company was directed against it, and advanced under a murderous fire. Both the battilion Commander aud the compans Commander accompanied the 7th zug, which was the first extended, and advanced to the right of, and in line with, the 2nd compauy against the farm.

In order to take the encmy more in lank, the riflemein crept along the ditch, already referred to, until they were able to bring their fire to bear on the farm from its north side. Shortly afterwards the two ziige of the company, still in close order, wero brought up to this point at the double. As soon as the company was recruited it dashed forward towards the farm, from which tho cueny withdrew in the direction of the main road.

The 4th company now established itself behind a garden wall fronting towards the road, and from thence brought its fire to bear upon the enemy's position.

During these occurrences the 2nd battalion was brought forward from its reserre position. With tho exception of the 5th company, which received orders to remain in close order at the castern issue of Vaumainbert at the disposition of the brigade Commneder, the bnttalion adraneed in line of company columus to the right of the road.

The 7th company formed the right flank of the battalion, and mored forward half right inmediately on the border of the village. With the 5th zug in advance, it pushed on, suffering heavy losses, to the vine-clad heights north of the village, and wrested from the enemy a row of houses lying to tho cast of them at the moment that the the company took the farm, as recounted above. From here the company joined in the advance of the 4th company.

The 8th company was to follow the 7 th, but, receiving a hot firo from the left flank, it took shelter in the nearest farm, which was occupied by detachments of the 2nd company. From here the company pressed forward with the 7th zug leading anainst the beights, while tho company Commander; with the 8 th and the rife züge, nored further to the right and established connection with the 7 th company. Gradually gaining ground, the company sncceeded in capturing a large building only 200 paces from the enemy's entrenchments, but any further adrance was impossible. A long stationary fire action now ensued with the enemy posted under corer in front. A decision could only be arrired at by sinultancous energetic action on the south side of the village.

We must recall the situation that had been developed here. As has been already related, the lst and 3rd companies were intended to operate on this side of the battle-field ngainst the enemy's right flank. The 3rd company advancing south of the road, found itself soon in front of an cntrenched liuc, opposite which lay the 35th Fusilicrs firing on it. The company joined them, and was immediately hotly engaged with the enemy at a distance of barely 200 paces. The 5 th 
zng was in front, opposite the shelter trenches, whilst. the two other züge were still in-close order behind a furm belonging to the village situated in rear.

'The lst company, still further to tho left, had occupied tro honses rery favourably. situnted for firing on the entrenchments, and kept up from here an effective fire on the enemy's position. In spite of this well-sustained fire action along tho cntire frout, for a long time it was not possible to suppress the enemy's fire. On the contrary, it increased crory moment in intensity. The flanking fire from a corver of the eotrenchment jutting out still further south, made itself particularly unpleasant. Tho losses inflicted from thence on our 5th zug and the 35th made it necessary for the rifle zug, and soon afterwards the half of the 6th zag, to extend against it.

The enemy lay, completely corered, in the shelter trenches. Their fire appeared to be delivered in part without aim; seldom was a head seen above the parapet for the purpose of firing. Still the attack on this position was most difficult owing to the open appronch which offered no sign of cover. Only very gradually single small parties succeeded in gaining ground to the front.

The resistance of the enemy appeared slowly to relax in face of the well-aimed firo and determined persercrance of our men. Thuir fire became wenker, and already single French soldicrs could be seen falling back in the direction of the main road. At this moment Bugler Selchow, of Blumberg, of his own initiative, sounded the "Advance rapidly!" The entire shirmishing line rose up, as if on the parade ground, and stormed the entrenchments with a ringing cleer.

After a short lalt, caused by re-forming and sending back the prisoners taken, the company, reinforced by a portion of the lst company, proceeded to the attack of the salient jutting out to the left, before which, during the general ndvance, a section of the rifle zug of the 3rd company had been left to occups the enemy. Emboldened .by the success just obtained, a long preparation by fire was not awaited. The assanlt was made with the bayonet, accompanicd by a lusty cheer. The entrenchuent was carried, and 40 unwounded prisutiers fell into the hands of the victors.

Those detachments of the enems winich had succeded in withdrawing from the entrenchments in time fell back to a large farm situated about 1:50 paces furtber back, and lield it. Against this the company Commander Jed the 5th and the rifle zïge, while the Gth 7 ug rallied in the entrenchment, and remained there in close order. After seizing a small farm on one side of it, in which ten prisoners were taken, the company brought an effective fire to bear on the larger buildings, which were then snccessfully assaulted, and 100 prisoners taken.

In the meantime the cuemy in the farm buildings, situated on the main road, had to retire owing to the determined adrance of our troops. The greiter number of the buildings as far as the bill rising behind the village was already in our possession. Two züge of our lst company were engaged here in coucert with the 35 th and the 6th company was further to the right. 
The lst company, after taking a large villa, had turned up a village strect parallel to the main road, and was engaged opposite the row of houses in front, which was still held obstinately by the enemy. 'Tlie lst zug had entered a park further to the left, and was able, from the park wall, to bring an effective fire on that portion of the eutrenchments still in the enemy's hands.

The 6th compang shortly after joined on to the right of the 3rd company. Here again the resistance of the enemy was overcome; the row of houses was captured and occupied. Tho village of Vaumainbert was in our hands. It was now 4.30 r.M. and night was falling. The enemy were in full retreat on Orléans.

The 12th company had been kept in reserve, and was not seriously engaged.

The losses of the 1st and 2nd battalious were 10 Oficer, 2 non-commissioned officers, and 12 men killed; 2 Officers, 7 non-commissioned officers, and 29 men wounded.

5th Jecember.-An adrance was made as far as Bourgogne, a suburb of Orléans, which city had been alreads occupied by the 17th Division during the preceding night. By its captuse the attempt made by the French to relieve Paris from the south was frustrated. The next point was to break up the remainder of the Loire Armsit had lost 20,000 men on the 3rd and 4th December-which was reported to hare divided and retired in three directions. The 3rd Corps and the lst Caralry Division had for their task to ascertain whether any large bodies of troops were in the neighbourhood of Gien and Jlontargis.'

The oth Decernber was a rest day.

7th necember.-The 1Ith Brigade formed the main hody for the - march. It assembled west of St. Denis at 8.30 A.M. The regiment went into march quarters at Chateauneuf and St. Martin d'Abat.

8th December. - The order to march reached the troops at 3 A.s., and they assembled at $S t$. Aignan at 8 A.s. $\Lambda$ s the advanced troops observed signs of incrensing resistance which led to the expectation of a collision with large masses of the enemy at Gien, the baggage was left with an escort in the cantonments.

$\Delta$ bout 4 bilometres west of 'Gien a halt was made, and, after a long period of waiting, the order was received for the buttalion to be cantoned at Dampierre and its neighbourhood, some miles in rear. The erening was pitch dark, and the troops did not rench their cantonments till 7 P.SI. On this day th:o regiment marched altogether $18 \frac{3}{4}$ miles, which, looking to the extremely nnfarourable condition of the weather, was a considerable performance. After a hard frost snow lad fallen. The roads were like glass, and on foot progress could onls be made with difficulty. Riding ras only possiblo with the shoes turued up, and was then extremely difficult.

9th December was a rest day, much needed for mending boots, which had suffered from the constant marching. The day of rest was followed by a disturbed night. About 9 P.3. orders were received for the battalions to march at once independently in the direction of 1 To the E. and S.F.-ED. 
Orléans. It wns carly morning when they reached their now quarters, Les Bordes, Bounce, and St. Père, after a vers arduous march. The reason for this sudden change in the previous arrangements was that the Grand Duke of Mecklenburg's force had since the 7th Decen. ber been seriously engaged with far superior forces of the 2nd Loire Aims. The II Ird Army Corps, thercfore, as well as the IXth and $X$ th Corps, was ordered to reinforce it.

10th December.-The march was continued on Orléans; the brigade assembled at St. Martin d'Abat, and thence the battalious marched by the shortest route to their now march quarters (St. Deiis de l'Hottel and vicinity); on the way the regiment was joined b5 an Ersatz druft of 1 Licutenant and $150 \mathrm{men}$, who were distributed among the companies.

11th December:-A short niarch bronght the troops about mill-ilay to Orlénus, where yanaters were provided, and in most cases the men were well fed in them. They also reccived an issue of tobacco and cigars, which were vers welcome. $\Delta$ regular transmission of cigars from home by post had been established; but latterly the postal serrice had not been up with the troops, so they had for some time becn without them. In Orléans also crbswurst was again reccived for use in times of emergenc5.

In order to hasten as far as practicable the march of the adraneod guard, of which the regiment had formed a part since the march back had commenced, 50 wagons of a provision column were placed at the disposal of the 20th and 35th Regiments, to carry their packs on the following das.

12th December.-The march of the advanced guard was continued to Bcangenes, where it remiliued the following day.

14th December.-It adranced to Mrares, from which point the.batta lions moved indeperudently to their cautonments at Conan and the neighbouring localities.

\section{Action of Coulommicrs.}

foth December.-The Xth Army Corps wins ordered to push forward a reconnaissance on Vendôme. The advanced gaard of the IIIrd Army Corps, together with a brigade of the lst Cnvalry Diri. sion, was directed to adrance by Selommes-Coulommiers-Villetrun, and from there to push on to Vendome, in order to grain news of the strength and the positions of the enemy, or else to support the morements of the Xth Corps.

The following was the order of march:-

1 squadron.

1st battalion 20th Regiment.

2 batteries ( 1 light, 1 heary).

2nd aud fusilier.battalions 20th Regiment.

1 The maps on which the further morenents of the regiment can be followed are those in the official account of the war, namely, 2SA in Scetion 14, 2Sc in Sec. tion 15, plan of the Battle of Ie Mans, Section 16, and the sleches giren in this last-named section.-ED. 
35th Regiment.

1 section of sanitary detacliment.

On arriring at the heights of Villemardy, packs were taken off. From Selommes tho fusilier battalion branched off to the left, to cover that flank of the udrance.

On a report being receired north of Villarecau, that the hostilo cavalry had appeared at Villetrun and fired on our cavalrs, the light battery was sont forward to a hill commanding Villetrun. Simultancously the lst battalion deplojed into line of company columns, and took post with two companies on either flank of the battery. After a few shots had been fired into the village, the enemy's cavaliy were observed withdrawing in a north-westerly direction.

The 2nd and 3rd companies, with skirmishers thrown out in their front, advanced on either side of the road against Villetrun, where some infantry still held their ground. The lst and 4th companies followed in close order as a balf batialion. The village was not defended, and Coulommiers, npon which place the adrauce was continued in the same formation, was found not to be occupied.

By order of the brigade Commander, the regiment occupied Coulommiers defensively; the lst unttalion was disposed on tho southern and western borders; the 2 ud battalion occupied a reservo position in the vicinity of the cliurcb. 'The fusilier battalion was directed to establish communication with the Xth Army Corps from the Houzéc valley. It might now be about 2 P.Mr.

The two batteries bad come into action north of the village, and thence fired on the enemy's artillers situated on the hoights sonth of Bel-Fssort. The 35th leginent had now already left its position bchind Coulommicrs, and deployed for action on Rocé, as well as in the mood west of that place. 'Iho 5th and 7th companies 20th Regiment. were in the meantine pushed forward to the siugle farm situated at the northern issue of Coulommiers, to cover the batteries.

At about 3.30 r.3r. the brigado Commander ordered a battalion to attack tluat portion of the wood situated on the opposite heights, which was sharply marked by a row of poplars in front. Tho advanecd guard Commander detailed for this service the 2nd battinlion 20ih Regiment, which adrauced in two lines in tho direction ordered. The 6th company was on the right flank of the front line, with the sth company on its left. The 7 th and 8th companies were in the second line orerlapping the left flank.

Tho ground rose towards the front in a gentle slope to a broal ridge. No enerny was at this time risible. But hardly had the skirmishers of the 5th and 6th companies reached the ridgo when suddenly the rattle of musketry broke out in their front, and a thick hail of lead whistled through the ranks of the battalion. Tho cnemy, posted behiud a hedge situnted in adrance of the wocd, had on this occasion, contrary to their usual practice, reserved their fire for the most effective range. The rolley delivered, at about 250 paces, was immediately followed by the hottest, rapid, independent fire.

At the first moment of surprise the whole batialion had thrown 


\section{HISTORT OF TIF 3RD BRANDENBURG INFANTRY}

themsclves down on the ground. Almust at the samo instant all appeared to be animated with the same fecling. "Forward and at them!" With a loud ringing cheer, shirmishers and columns rose up, and threw themselves, without firing a shot, upon the eneng, who thought it lest to retreat at a very rapid pace. On arriring at the hedge, the 7th and 8th companies were also extended in the advanced line.

On the other side of the liedge lay a meadow, the north side of which was also bounded by a thick hedge. From thenee the enemy now receired our skirmishers with a hot fire, whilst on each side, to - the right and left, the troops driven ont of the former position disappeared into tho wood. This well-considered retreat, in which cridently a rapid clearing of the front of the new position had been kept in view, eridenced a better and surer leading than had been observed in our former engagements.

After a short fire action, and after all had got through the hedge, an adrance vas made at the doublo against the new position. The Captain at the head of his company gare the first impulse to this adrince. The cuemy again fell back into the real position on the border of the Bel-Essort wood. Along this extended the row of poplars, visible from a long was.

'The ground rises gently from the hedge now evacuated to the wood, and is covered witll thin bush. This bush is completely orerlooked, and can be kept under fire from the edge of the wood. In prolongation of the wood torards the east a shelter trench had been thrown up, and was occupied by the enems.

After taking the hedge, the 8th company receired orders from the battalion Commander to asscmble, and to follow the adranced com. panies as reserve. The company assembled in a rarine running in front of the wood, and remained there. The other companies con. tinued their attack on tho wood, pressing forward from copse to copse. Whilst the 5th company, whecling slightly to the left, took a portion of the border of the wood in flank, the 7th comjany joincd this morement on the extreme right flank, and in its further adrance cleared the shelter trench. The 5th company penelrated simultaneously into the easterly corner of the wood, and thereby foreed the enemy to gire up the border of the wood.

The 6th company which, situated on the left flank of the battr. lion, had not found it possible to make rapid progress, was placed by the wheel of the 5th compauy in rear of its firing line. 'The Com. mander therefore assembled his skirmishers and joined the 8th company.

Whilst the 5th company occupied the edge of the wood, the 7th company on the right flank succeeded in occupying a clay pit, from which could be brought under fire the further border of the wood, and the open ground bejond, which had to be passed by the enemy in his retreat from the wood.

Shortly afterwards the 5th company also-pressed forward to a ridge north of the wood, from which also this open ground could be brought under fire. 
The darkness setting in-it was 5 o'closk-as well as its isolated sitaation; forced the batfalion to make a short halt in its victorious adrance. After a patrol had been sent to the large wood lying eastwards, and reported it to be occupicd by the 3rd battalion 35th Regiment, the advance was continued to La Foret farm, where the battalion received orders to halt and assemble.

Notwithstanding the fatigues of tho day and the falling min, the men were in excellent spirits at the success gained, and jokes were indulged in frecly. One source of merriment was the Ersatz men, who for the most part had for the first time been ander fire. Tho important order to search for bullets after the close of the action was given them. "A lance corporal and six men to the front, to look for" bullets!" was the joke of the day.

About 7 P.Is, a dragoon brought the order to the brigade to march into quarters at Villetrun, which placo was reached by tho battalion at 10 p.yr.

The lst battalion had not come into further contact with the enemy; neither had the fasilier battalion; which, as has been scen, was detached to maintain communication with the Xth Army Corps. Tho losses of the 2nd battalion were 7 killed and 39 wounded.

16 th December.-The whole regiment was cantoned at Villetrun, which proved rery close quarters.

17th December.-The 20th Regimeat; together with the 35th liegiment, two squadrons of dragoons, and two ficld batteries (one light and ono heavy), a sanitary detachrnent, and a field hospital, were constituted until further orders the "1lth Combined Infantry Brigade.",

In consequence of tho news received from the Upper Ioire, the march back thero was ordered, and the brigade assembled enst of Villetrun at 9 A.Y., and reached at 1 P.Y. its new quarters at and about Marchénoir. Though not actually raining, the roads were almost impassable.

18th December.-Assembling at 9.15 A.\$., tho brignde renched its next march quarters at Beangenc5, at 2 P.y., the packs being carricd for the men. It halted there the following day. The lst company was detached as escort to the $\Delta$ rmy Corps propision columns. About thirty men of the regiment, unable to march, together irith others froin other regiments, were also detached for stationary duty at Mer with the depurtments.

On the evening of the 19thi orders were received for the IIIrd Army Corps to go into extended quarters and rest for some'days. The new's was received with great joy, for, apart from tho rest being very welcome, both clothing and boots had suffered severely from the constant. marching in all weathers on bad roads, and repairs werc urgently required.

As soon as the troops had settled into the allotted quarters, all the arailable tailors and shocmakers were set to work, the nuaterials for repair being in part served out and in part obtained by requisition. Even billiard cloths were employed in repairing the men's conts and trousers. It was many days before the piles of clothing and of boots 


\section{HISTORY OF THE 3RD BRANDHASURG INFANTRY}

for repair showed any material diminution in bulk. As articles wero carried away; others were brought in, to the despair of the workmen.

At the same time the arms and accoutrements underwent a thorough cleaning and inspection: workshops were established, and all necessary repairs carried out.

On the 30th a convoy arrived from the Ersatz battalion with 750 long boots. Almost all the men were now in possession of two paire of serviceable boots.

\section{1.}

\section{From the Loire to the Sarthe.}

On the 1st Jannary tho 2nd Army received orders to take the offensire agninst the enemy adrancing from the west, from the line Vendôme-Iilliers.

3rd January.-The regiment marched in brigate to Beaugency, where it was rejoined by the lst company.

4th Jauuary. - The regiment marched independently to St. Leonard and IInrchénoir, with tho exception of the 7 th company, which had preceded it, accompanied by. a cavalry zag, to patrol towards the Bauvillicrs and Villegomblain forests.

5th Jamuary.-The brigade assembled at 10 o'clock at the eastern outlet of Oucques, and marched to Noyers. Thence battalions moved independently to Renay, Champlain, de.

The 9th company was detached to form a guard to the $\Lambda$ rmy Corps Headquarters.

During the entire march the fog was so thick that it was impos. sible to see more than 50 paces ahead. In the erening patrols were sent out from all the cantonments in the direction of the Loirc.

\section{6th January.-Action of Azay-Mazange.}

The strength of the regiment on this date was as follows :Regimental Staff and lst

battalion............ 15 Officers, 44 non-com. oflicers, 66.1 men. 2nd battalion......... $12 \quad " \quad 59$

Fusilicr battalion ...... $13 \quad " 42$

T'otal :..... $40 \quad, \quad \overline{145}$

". $\quad \frac{602}{1,893} "$

Reliable information had not been receired of the cnemy. To all appearance he had occupied the Brajo position, and intended from there to make strong offeusive movements.

The 6th Division received orders to cross the Loire at St. Firmin and Meslay, and from there to gain tho Azay position with its advanced guard. This was composed of the Ist and 2nd battalions 20 th Regiment, the 35th Regiment, 2 squadrous, and 2 batteries.

The fusilier battalion 20 th Regiment, with $1 \frac{3}{3}$ squadrons ind a pioneer company with light bridging train, formed a flank detach- 
ment on the right. Tho brigado assembled at 10.30 and crossed the Ioire, by the bridges which had been reestablished in the early morning. The cavalry was in adrance, followed by the 2nd batta. lion; then a battory, followed by the lst battalion.

The 5th and 8th compavies, with a zug of cavalrs, wero detached by Belair-Chatenu to advance on the Fendome wood, clear it of the enems, and then more in the direction of Azay, and corer the right flank of the adranced guard.

The remaining six companies of the regiment, with the advanced guard, reached the Vendôme-Epuisay road about noon. When the column had arrired on the alignment of La Briochetterie, reports werc received from the cavalry patrols that the rear edge of the Le Plessis ravine was occupied by the enemg's infantry. The 6th aud Tth companies, leading the achance, were deployed at once into cospany columns, the leading zug of each company cxtended, and they advanced, tho Gth company on the right, against the ridge.

The Ist battalion followed in column, in rear of the centre.

The two companies advanced at a rapid pace, without fiving a shot, and drore back the adranced detachenents of the enemy.

The enemy had apparently occupied in force the farm of $I_{2}$ Charbonnerie, situated about 500 paces in front. The lst battalion now deployed agrainst this. The lst and 2nd companies wero placed on the right in extension of the 6th company. The 3rd company was to follow in support of these in close order. The 1th company was placed in reserve behind the 6th and 7th companies.

An adrance in the direction of the innin road was hardly practicable on account of a heary flanking fire from the wood and the Georgeat farm situated on its border; line was formed in this direcand a sustained fire brought upon it, assisted by a battery at $L_{a}$ Merillière.

As, however, the 6th and 7 th companics had been brought to a stand, and a rapid advance was not to be expected without reinforcement, it was determined to assault La Charbonnerie without further delay. The line gradually worked its way up to within 300 paces of the farm, and then successfully stormed it.

The encmy fell back across the meadow valley of the Boulon stream to the ridge bejond, and oscupied the rillage of Azay on the slope, and the buildings and thick stone fences which here trarerse the country in all directions. A hostile battery camo into action east of the village, and fired on the slope.

$A$ heary fire action was now dereloped against the enemy, and especially agrainst the village of Azay from the opposite ridge.

'L'he troops gradually pushed on into the low-lying meadows; but no decisive effect conld bo achieved against the encms, who were sheltered behind the houses, walls, and hedges. After a brief preparation, therefore, the assault of the village was ordered.

The 2nd and 4th companies led the advance, the lst company making a turning morenent towards the northern issue. The 5th zug of the 3rd compans, which at this time occupied the La Fosse baildings with tro zoüge, joined in the adrance. 
By 3 P.Y. the village of Azay was caried by $3 \frac{1}{3}$ companies of the lst battalion and detachments of the 35th Regiment.

- In the meantime tho 6 th and 7 th companies pressed forward on the left, and succeeded in gaining the Isa Galette buildings.

At 4 o'clock, when it was beginning to get dark, the fire suddenly increased in intensity along the entire line, and tho enemy made a desperato attempt to take the offensive.

All available troops wero pashed up into the firing line to meet it, aud the advanco melted away before the tire brought to bear on it from all sides.

About $90^{\prime}$ clock r.y. the 12th Infantry Brigade arrired to take orer the outposts for the night. Our battalion marched back at once to tho quarters allotted to them north of Vendome, where they arrived late at night. The losses of the Ist and 2nd battalions wero 13 Officers, if non-commissioned officers, and 101 men killed and wounded.

The fusilier battalion, with the right flank detachment, reached Danzé.

7th January.-Tho brigade assembled at 9 A.M. at Courtiras. In ammnnition column was waiting drawn up on the road, from which the ammunition was completed.

Prince Frederick Charles rode up and iddressed the regiment: "You havo again fought as brarcly as jou always do, only too impetnously ; hence the heary losses." The joy of the men at this honourable recognition from the lips of their distinguished leader was to be read in their benming faces.

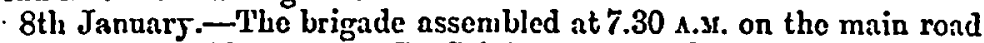
near Poirier. About noou St. Calais was passed, and shortly before 4 r.3. the regiment was told off to quarters in Conflans and neighbouriug farms.

9th Jannary.-The orders to march reached the regiment at 5 o'clock. The brigade was ordered to be formed up on the main road opposite Le Mlesnil farm at 8.30. Owing to the companies of the Fusilier Regiment being scattered about the assembly of the regiment could not be effected before 9 o'clock.

i In accordance with a divisional order, the more serious cases anongst the sick were scut back to Sarigny, to be conveyed thence to Orléans by the Army Corps columns. As escort, thirty-five footsore men and stragglers were detached from each regiment.

The continued fatigues of the march increased the sick list from day to das. The cases of frost-bite of the extremities were especially nnmerous; but were fewer on fighting days than on days spent in marching, when the main body followed the advance guard at a vers slow pace, repentedly interrapted by long halts.

- The sick in hospital on the 7th January numbered 3 non-cornmis. sioned officers and 45 men; and on the 12th Januars, 6 non-commissioned officers and $71 \mathrm{men}$.

Whilo the 12th Brigade was engaged at Ardenay, the regiment had to remain for hours at the junction of the main road and the Surfond-Le Breil road. Dead tired be the march on the slippery 


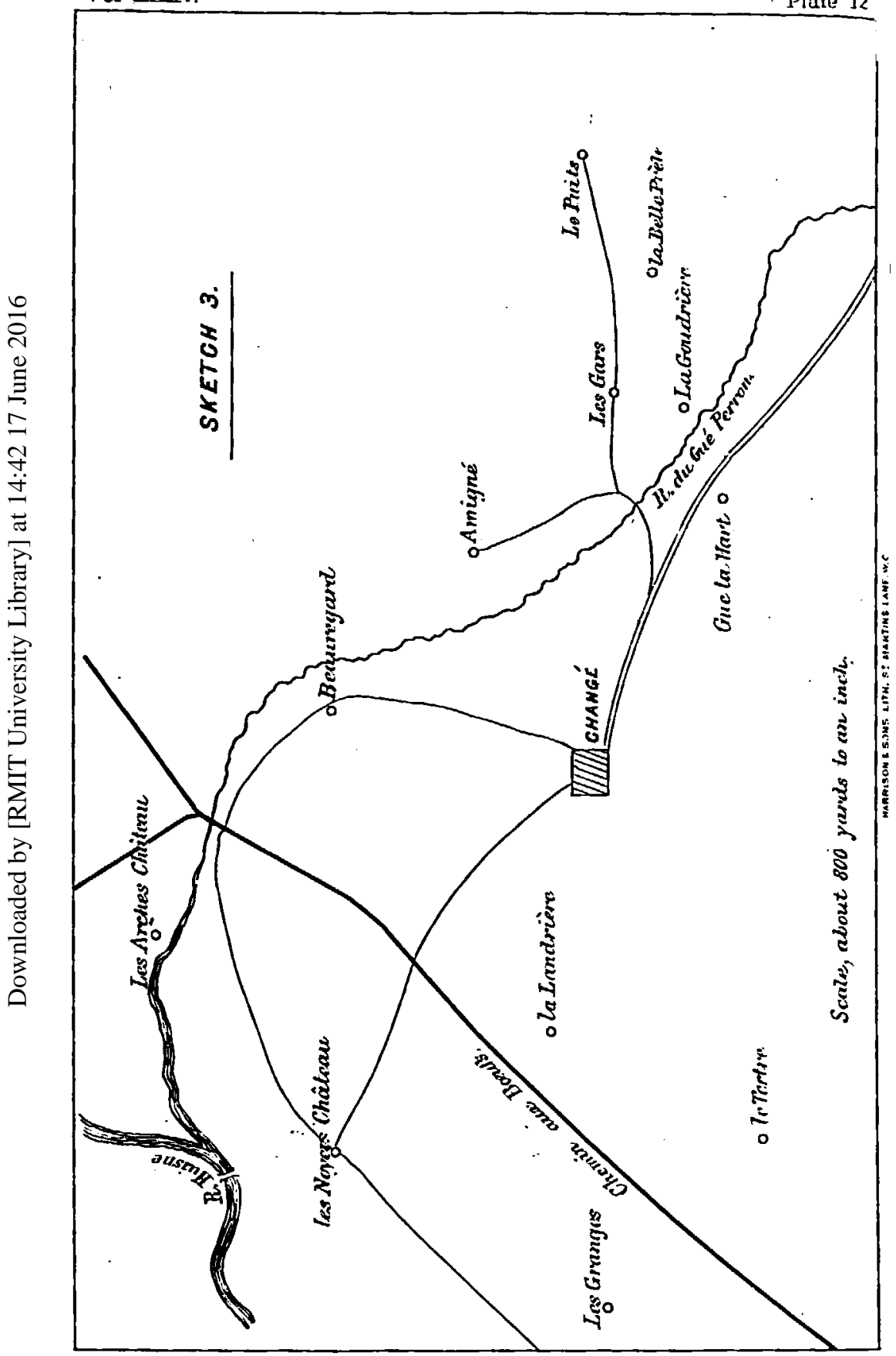


road, and wet to the skin, the men threw themselres down in ditulies filled with decp snow. After 7 o'clock P.M., tho ordor arrived at last for them to go to quarters, the Staff aud fusilier battalion at Ise Breil, the lst battalion at Soulitres, the 2nd battalion at Nuille.

\section{Batlle of Lie Mans on the 10th, 11th, and 12th January.-Engagenent at Changé on the 10th. (Sec Sketch 33.)}

It appeared from the reports that the XIIIth and Xth Army Corps, on tho right and left flauks respectively, wero far from having reached their objectires, and that the IIIrd Corps was in adrance in the centre liks a wedge. The intention, on the contrany, lind been to cal ry out an cnveloping attack. Notwithstanding this, Prince Frederick Charles ordered the advance of the IIIrd Corps to bo continued.

The enems was to be attacked along the entire line ChampagneChangé, and to tho left as far as Parigné l'Evêque, in order to facilitate the advance of the Xth Corps on the Grand Juce road.

An advance in four columns was ordered by the Corps Commander. The 12th Brigade was. placed on the extreme right flank, and advanced by the Ardenay-Lc Mans road. 'The 11 lih Brigade noved on its left, turning to the left at Arlenay, through the Bois do Loudon on Changé. The 5th Division advauced on the left, also divided into two columms, in the general direction of Parigné l'Erềue.

This advance led, on each of the four roads, to scrions fighting.

The proceedings of the 11th Brigade ouly will bo followed here.

'itho lst and the fusilier battalious' marched at 8 o'clock to tho brigade assembly at the cross roads Bouloire-Lc Mans and Surfondlo Breil. In accordance with superior orders, the and battalion remained at Niullé to protect the right flank.

$A$ thick for lay on tho morning of the 10th orer tho snow-covered fields. Tho air was somewhat milder, but this intensitied the slippery condition of the roads. It was hardly possible to ride.

At 10.30 A.s., the nilrance was commenced from the place of assembly; the 3isth Regiment led, followed by the two battalions.

$A$ bout 3 o'elock, the adranced guned-and battalion 35th Recriment - came into confact with parties of the enemy at Le Puits, a farm situated about 2 kilometres east of Changé. $\Lambda$ brisk action ensued in which the whole of the 35th Regiment was soon engaged. Tho cnewy, at first driven back along the entire line, was soon reinforced to such a degree that at some points an adrauce conld ouly be made very gradunily through the close countrs devoid of any clear riew; whereas at other points the positions already gained could be maintained only by graat efforts.

The 1st battalion 35th Regiment was detached from the right against the enemy's left flank. As owing to the loug and difficult way, the early action of these companicy was doubtful, our fusilier battalion received the order about 3.30 P.3. to advance north of Les

1 Ono zug of the 11th company remained at Lo Brcil, to guard the hospital.

rol. XXXY. 
Gars on Amigné-Chittcan, in order to relieve the pressurc on the parties of the 35th Reriment fighting beyoud that farm.

On arriving abreast of Ins Gars, the 9th company was adranced against the copse lying north-west of that farm, with a ricw to establishing from there comnuniention between the lst and 2nd battalions of the 35th Regiment, and to supporting the attack in in westerly direction. The 2nd zug of this company occupied the hedgo of the garden helonging to tho farm-honse, and from thenco carricd it the first rush the sonthern borter of the alder plantation besond.

During the advance the zug had been molested by fire from the; left flank, directed on it by the enemy from Ise lavillon farm. 'the two other zuige, therefore, procecded to attack the farm. Rumning forward from one quick-set lielge to auother, thes succeeded in reaching a decp ditch lying sonth of and at abont 250 paces distance from the farm. From thenee thes opened a lively iudependent fire on the houses and walls of the farm.

The other companies of the battalion had, in the meantime, con. tinued their advance along the main road. Beyond Les Gars, they moved off the road in a northerly direction in order to gain the riglit llank by passing behind tho companies of the 35th llegiment engaged here. 'The extentled 35th, in the direction of the stream of Gue Perray, stufered scnsiblo losses licre from flumking fire from a northerly ind north-westerly direction. The Commander of the fusilier battalion 20th Regiment, therefore, directed the 10th company to advance to the left of the country road to Amigne against an alder thicket abreast of Tue Parillon.

The 4th zug pressed forward up to a hedgo rnnning diagonally up to this thicket, and was at this moment supported on its right by the 3rd zug, which had been led ap by the company Commander himself, who was wounded, and his place taken by a Second Ijicutenant.

In order to strengthen tho fire at this point, the 12th company; which had hitherto remaincd posted in rescrve on the road, was now ortered np. It took post on the right of the 10th compans. Adrancing along a thich-set liedge, it soon reached a ditch, from whenco the alder thicket could be outflanked. $\Lambda$ fter the first shots the encmy began to gire way. Their retreat was conrerted into a confused flight, when immedintely afterwarls the hurrah of the two companies resounded, and the'se rnsh forward to the border of the thicket. 135 the time thes renclsed this, the enemy had disappeared into the wood.

In the further adrance the 12 th company. moved with its right in touch rith the 9th company, which was posted belind a hedge rest. of the thicket and parallel with it, and firing on Le Parillon. Thu inem5, shaken by tlec troops falling back from the alder thicket, now gave way here also, and retreated from the farm in a northerlydirection upon Amigné-Chateau. The next moenent our men crowded into Is Pavillon froin all sides.

With a riew to the attack of the chitcan and the wood situated belind it, the 9th company received orders to move further to its

1 I cannot fis the position of this farm,-Tin). 
right, in the direction of a wet ditch, to seck for a crossing point further up, and then to adrance ugainst the eastern border of the wood.

In front the 5th zng of the 11th company had now joined the left flank of the most adranced fighting line. During the adrance on the chateau it made prisoncrs a post of sistecn firenchwen, whom it surprised.

In the meantime tho 9th company had reached the further bank of the watercourse, and had just formed front towards the chat tenu, with the 1st zug on the right, when some of the cnems's riftemen came ont of the wood in front, pressed by parties of the 33th Regiment, who followed them with " hurralı !" 'The company was able from its sheltered position to dircet aimen fire without hurrs, and at barely 200 paces distance, on tho retiring enemy. It was one of those very rare moments in the ficld, where every man was able to observo the effect of his own fire. 'The enemy left on this spot a number of killed and wounded.

The other companies of the fusilier battalion, and on the extreme left flank a company of the 35th Kegiment, having gradually gained ground from hedge to lodge, lad nlso crossed the stream and were eugaged in a fire action against tho chitean. When the fire from thence began to slacken the buildings were earried by a general alvance. Orer fifty Fronchmen were found in the chateau and unade prisoners.

Shortly afterwards the 9th company also arrived there.

After the companies had assembied, tho battalion Commander ordered the 9th and 12th companies, the latter on the right, to examine the extensiro park. Parties of the einemy were found in it, but they offered a rery slight resistance.

While these occurrences were taking place, our 1st battalion had not been idle. Soon after the fusilier battalion had become engaged, it had received abreast of Ies Gars farm the order to adrance south of the Change road, and to move round two companies sufficiently far to turn the enemy's right flank. The latter had occupied the group of houses that are sitaated opposite to the passage of ArdenayChangé road over the Perray stream, and held it with great determination. The energetic attacks by the 35th Regiment had up till now been driren back with heary losses.

'I'he 2nd and 3rd companies reccived the order to adrance along the road and support tho front attack by the 3ith Regiment. The 2nd company extended one zug, and placed itself north of the rond, on the right flank of the troops already extended there, which were directing from the bank of the stream a lively fire on the Gué Ja Hart farm. Shortly afterwards the other two ziige were also brought into the fring line. For the moment further progress here was impossible.

The 3rd company mored south of the road, and aligned itself with the 35th Regiment on the left tlank, occupying a liedge in front of the Goudrière farm.

The 5th zug succeded in crossing the strenm, and sheltering itself $3 \mathrm{z} 2$ 
in a hollow way immediately before Le Bordage, on the Parigne-Bordé road.

The other two companies-the lst and 4th-were led between tho farms of Goudrière and La belle Prêle, in order to undertake from tho left bank of the stream the attack on the south side of the farms; by the help of ladders and planks the stream was crossed with small losses, notwithstanding the heary fire by the enemy.

On the other side of the stream the Officer in command of the two companics found two companies of the 35th in front of lim, which bad crossed it earlier, and were now firing on Le Bordage. Portions also of the 5th Dirision had towards the erening been directed from the sontherly roads upon Changé, and now came into touch with our two companies on the left flank.

The various units thus collected here now precipitated themselres with a lusty hurrah upon the buildings. After a bricf struggle, in the course of which it often came to hand-to-liand fighting, the posi. tions fell into our hands.

The 2nd battalion, as alrealy relnted, had been left kelind in Nuillé. $\Delta t 11.30$ it marched, by order of the division Commander, by Le Breil, Ardenay, and Rossny to rejoin the regiment. It arrived at Changé at 4.30 p.s., before the decision had taken place at Gué la Hart, and was ordered to the Ises Gars wood in reserre.

$\Delta$ bout 6 o'elock the regiment Commander received orders from tho brigade Commander, and almost simultancously from the corps Commander, to adrance with the 2 nd battalion on Changé and seize the wooded heights to the west of it. T'wo companies of the fusilier battalion-the 9 th and 12 th-were ordered to support the movement on tho riglit flank.

Immediately on crossing the water-coursc, which is trarersed by the main road, hardly 200 paces from the village, the battalion was fired at from its border. 'Tro companies-the 6 th and 7 th-extended to the right and left of the road, and brought their fire to bear on the village. After a long fire action, lasting for nenrly half an hour, all moved forward to the attack. In the villago our men met the 52nd. The enemy gave way on all sides, followed closely by our troops, who pursaed them as far as the heights bejond Changé.

It was now past 7 p.s. The firing shortly died array on both sides, and the engagement was at an end.

- The 1st and 2nd battalions took vp alarm-quarters late in the crening in Changé. The place ras so fully occupied with Staffs, troops of the 5 th Division, prisoncrs, nud wounded nen, that place could not be found for all to lie down. Still they rejoiced to haro a roof over their heads during the cold night.

Outposts were placed by the fusilier battalion on the heights west of Changé. In the snow, with 8 degrees of frost, without wood or straw, tho fusiliers passed a night of hardship. Their food also was insufficient, for the baggage had not been ablo to get up owing to the slippery roads.

Notwithstanding this the spirit of the men was excellent; they conforted themselves with the thought that the French were suffering 
still moro than we did from the cold, as could be scen by the miserablo appearance of the prisoners. In the early morning, when all in the bivouac were stiff from tho frost, a wag was not to be denied his joke. He remarked that he had not been cold for a moment during the night, explaining, "I had two helenets. With one I corered inyself, and the other I put under my head as a pillow." .

The losses of the regiment were comparatively small- 2 killed and 12 wounded. The result of the action was billliant. The IIIrd Corps had pushed forward close up to the enemy's main position. The corps on each flank had also moved forward successfully.

\section{Engagement at La Landrière and Le Tertre on the 11 th and 12 th January, $18 \mathrm{il}$.}

During the night the order reached the regiment to complete the men's supply of ammunition at once. The ammunition wagons wero to bo filled up again carly next morning from an infantry ammanition column situated at Cliangé.

Prince Frederick Charles liad ordered a continnation of the attack by the IIIrd Army Corps, in the direction of Le Mans, for the following day:

The troops had been severely cxlanusted by their previons efforts, but the Prince judged it to be of the utmost importance to hold the eneray in the centro of his positions on the Huisne stream, so as to prevent his falling on the XIIIth Army Corps, which was threatening him by a turning morement on the north.

At this time it was beliered that the enemy's main position was on the heights situated on the further side of the strenm, and that thero were only strong detachments to bo dealt with on the near sidc.

After the attack only it ras learnt that the main force of the enems was posted on the wooded heights, running to Champagné, on the Huisne, north of and in a direction parallel to the Chemin-auxBucufs. The IIIrd Army Corps had three hostile divisions in front of it.

At 8.30 A.3r. the 11th Brigado assembled in a meadow east of Changé. At 10 o'clock the adrance was commenced by the Changéles-Arches road. The brigade had for its task to attack from the Perras stream the left flank of the enemy posted on the heights, and to hold the passages of the Huisne stream at Les Arches Chateau and Les Noyers Chattena agninst the enemy situated on the Aurours heights, and on the right bank of the Huisue until the arrival of the 12th Brigade. Tho 5th Division was to advance simultancously to the front apon Le Tertre.

In the ucighbourhood of Beanregard farm the outposts of the fusilier battalion wero dramn in. T'he battalion receired orders to assemble towards the right flank and follow in rear of the Brigade. The 35th IRegiment was told off to occupy Les Arches, it halted at the passige orer the strean south of the castle, and propared it for defence.

Our regiment continued its march from herc, the lst battalion on Les Noyers Châtcau; the 2nd battalion, wheeling to its left, through 
tho wood south of Les Arehes; the fusilier battalion followed in close order in rear of the centre.

At the point of junction of the Chemin-anx-Bœufs with the Ires Nogers Cliatcau-Changi road, tho advanced line of two companies (the 7 th on the left, the Sth on the right flank), ench with one zug extended, moved by their right and with the left resting on the road, and examined the wood in front.

The extended züge had hardly reached as far. as the MIaison Blauche, when they were received by shirmishers' fire, and suffered somo loss.

The enemy were posted in a thin fring line at a ditch which offered then shelter, in the middle of the wood. At that moment the order was given to the two companies by the battalion Comuander"Double!" The companies rushed forward with the lnyonet cheer. ing, and drove the encmy back. But a long closed lino came into riew through the thin brushwood. The enemy in the strength of at Isast two battalions was doubling forward to restore the fight. 'The battalion Commander mored up the other tiro companies of the list lino at the donble, the 5th on the left, the 6 the on the right flank. The cnemy was agnin charged with a cheer: 'They paused, delivered a terrible rapid tire, and then fled, followed by our men, who in a few minutes were in possession of the hostịle position, a hollow way at the cdgo of the wood.

The cuemy took up a fresh position in a wood opposite. On the left an cloration covered with small fir trees was strongly occupied. A stationary fire action was now engaged against this beight and the wood, during which the companies posted in tho hollow road suffered constant losses, notwithstanding their excellent cover. The cause of this was soon discorered. During the incautious advance of tho battalion a farmstead, La Landrière, situated on the road, had been disregarded. It was still occupied by the enemy, and gare them the opportunity of firing on the flank and renr of our men in the hollow nas.

The fusilier battalion had been moved to the left, behind the 2nd battalion as a reserve, and from it the 9th and 12th companies were sent against the farn. The 10th company received at the same time tho order to becp up communication with the Ist battalion. To this end the 3rd zng was detached to the right to tho path through the wood; the remainder of tho company was kept temporarily behind the Sth company in close order.

The 9th company went forward to the left of the rond, tho 12th company in the wood close to its edge. Covered by hedges and brushwood, which stretched to its left close up to the path, the 9th company succeded in getting to within 150 paces of the farm. The 12th company had adranced simultaneously by the edge of the wood to a position north of it. After tho needle-gun had been at work for some time from both directions, the order was given for the assault. The buildings were carried with the bajonet, regardless of the cuemy's firc, which was kept up with great determination from tho windows and roofs. 
Whilst the fusilicrs advanced rictoriously on the loft flank; the 6th and 8th companies on the opposite flank had succeded in occupying in quarey situitcel about 150 paces in adrance of tho hollow way, in a clearing in the wood. From this spot there was a clear feeld of fre to the beights on the left front. Parties of the encmy were driven by this fire from the fir woods in front, behind the crest of the heights, whence a lively fire was kept np against tho edge of the wood and the La Landrière homestead.

- Alreals, shortly after this had been captured bs tho fusiliers, the 12th company had attempted an independent attack on the heights. Inut it land to be abandoned on account of the superiority of the enemy; who took the offensiro. from tho fir wood on the approach of tho attrckers. The company withdrow with loss into the wool, as far as the hollow way, and had now agaiu taken position between the 9th company, which had advanced as fnr as a hedgo west of the homestead, and the left flank of the 2nd battalion (5th company).

On the order of the battalion Comnander, both zijge of tho 10th conpany were now bronght up here. Thes extended to the left of the l2th company on tho edge of the wood:

The three consanies in common now fired on tho heights; the and battalion joined them; the 6th and 8th companies extended to the right, further forward, and came in here very effectivoly. The more the enemy suffered from the Gre, the greater importance he secmed to place upon holding on to the hoights. Fresh troops were continually brought into the adranced line. An almost nervous morement was apparent with tho enemg. It was taken by us to indicate the commencement of their withdrawal, particularly as at certain points inclividual men could be seen to go back. "It is time!" shouted ons Officers to one another, " $\mathrm{U}_{\mathrm{l}}$, hurrah!"

All rose up for the result. At the same moment the French were to be seen advancing on us from the brashwood. The unensiness had been nothing more than the preparation for the offensive. Hat our brave Mlürker ${ }^{1}$ were not to bo confused by the enemy's advance. Without any special order being given, the drummers beat the charge, the buglers sounded. The enemy stopped and began to fire; but he soon learnt that the 20th were in bloody carnest with their attack.

He still lesitated for a moment, one could see how the Officers exerted thenselres to get the lines forkard; then all turned about and hastened back to the heights, which were reached almost simultaneously by our compnnies, so that destructive losses could be inflicted on the retiring Frenchmen by our rapid fire.

On the other side of the clenring, even the enemy had been unable to withstand the gerieral advance and abandoned his position-a ditch with perpendicular banks-which was oceupied by tho companies of the 2nd battalion.

A portion of tho men had pressed on besond tho ditch in the excitement of the attack, and followed the retiring Frenchmen sloso ap.

I $A$ name for the inlabitants of the Brandenburg Districl, to which the regiment belonged.-Fiv. 


\section{HISTORY OF THE 3RD BRANDENBURG INFANTRY}

to the far edge of the wood. Amongst them was Private Wille, of the 7th company, a native of Berlin.. He suddenly found himself in the presence of three Frenchmen, who pressed in on him and tried to drag him off. But in spite of a wound in tho hand, he succeeded in holding his own in the hand-to-hand fight until other men came ap and overpowered the Frenchmen.

In the meantime on the left flank still further progress had been macie. $\Lambda$ battery camo op on the heights south of La Landrière, and after long search found a position on the road from which it could firo on a group of houses, Les Granges, situated on the edgo of the wood, which was occupied by the enemy. Lincouraged by tho co-operation of the artillers, tho Commander of the 12th company led it and a portion of the loth company out of the wood as far as tho rond, and stormed the buildings.

The first care of the companies was now to place Les Granges a stato of defence. Tho seven companies had now adranced so far, that the 5th Division, at Lo Tertre, was fighting almost in their rear. Not the noise only, but still more the bullets falling from that direction, made as aware of this fact. It was 1 P.jr.

The men were still occupied in making openings in the walls abntting on the front, which were completely devoid of windows, when a battery moved up soath of L'Epau, and shelled the buildings. Soon infantry masses ndranced by the road. In spite of the works of fortitication being hastened on, it was not possible to completo them. They had to be abandoned, and a hedge with ditch at the side of the homestead was occupicd. From thence a veritable shower of lead was poured on the advancing Frenchmen. Presently; howerer, the situation began to become very serions. A strong hostilo column appeared on the slopo to tho left, and threatened to turn tho fusiliers. The 4th zug, loth company, was detached to meet this. Bat the superiority of the French, now pushing on from all sides, was so great that the homestead had to be abandoned. The fusiliers fell back with heary loss in a northerly direction on the rond. Only now could it be seen with what strong masses this offensive morement had been endertaken. The enemy liad brought up another brigade from the reserre, so that now the two battalions were engaged with an entire division of the enemy.

The enerny's attack had been made with equally superior forces against the and battalion in tho wood. Hore also the companies, with the exception of the 5th company, posted further back, pressed from all sides, had to give up thoir endangered position, to sare themselves from complete destruction. The fight slowly moved back. But the battalions took post in tho hollow way, tho first position captured from the enem5, with the fusiliers in the La Landriero farm on the left, determined not to gire way a foot further, but to wait there the arrival of reinforcements.

As at the commenecment of the fight, the 2 nd battalion was on the right flank with the 10th and 12th compranies on its left. The 9th company was in the farm.

Shortly before, so soon as the great superiority of the enemy was 
recognized, the Adjutant of tho 2nd battalion had been sent to tho regimental Commander, at Les Noyers Chatcau, and the Adjutant of the fusilier battalion to the 35th Regiment, to nsk for support. At the same time the regimental Adjutant had ridden back to fetch up an ammunition wagon, as the 2nd battalion was becrinning to run short of ammunition.

The cuemy had fixed $a$ limit to his advance in the uiddle of the wood. Ho was now situated at a distanco of barely 250 paces from the position. A furious musketry fite broke out along the entire line.

Gradually the fire on our side almost ceased, by order of the Officers, on nccount of the lack of ammunition. The enemy, appa. rently encouraged by this, immediately resumed the offensise; but the noment they rose up, such a rapid fire was directed on them that they abaudoned the attempt after the first few paces. A second attempt was unade to advance, but with a similar result. In face of the stcady benring of our men, any purely frontal attack was bound to fail.

In the menntime the 2nd and 3rd companies bad come np from Les Noyers Château, and taken position by the 6th company. It was high time, for the encmy, constantly pushing forward on his left flank, threatened to outlank our right.

Our ranks became thinner and thinner in this long fire action. The 2nd battalion was almost without Officers. Yet there was no nnsteadiness, no apprehension. Gradually, and owing to the increasing lack of ammunition, the situation of our troops bad become worse. Already the cariridges had been taken from the dend and wounded men and distributed; cartridges had ulso been brought up in harersacks and haudkerchicfs from the two companies of the lst battalion. Again the enemy had tricd to advance; and, brilliantly as this attempt had been hindered, still a renewed attack could only bo regarded with anxiety, for some of the units had literally fired their last round.

The first support was receired from the fusilier battalion. Its Commander, so soon as he heard of the difficult position of the 2 nd battalion, sent his 9 th company from the left to the extreme right. The 3rd battalion 35th Regiment occupied, directly afterwards, tho Lik Landrière laamlet in its place.

As soon as it was reliered, at Les Arches, by the 12th Brigade, the Fusilier Regiment (35th) had moved to our support. Its 3rd battalion had now arrived on tho left flank. Shortly afterwards the two other battalions brought direet support to our pressed right flank. Our 2nd battalion, that had suffered the most and had fired all its ammunition away, assembled on the arrival of these reinforcements belind the fighting line, as 2 nd line, and soon afterrards completed its ammunition from the wagons which had been brought up witl great effort.

It only remains now to turn to the action of the 1st battalion. As already recounted, it had adranced agninst Les Noyers Châtena, and, finding it unoccupicd, took possession of it and set to rork to prepare it for defence. Admirably adapted by its situation for defence, 
the castle mas, on the one hand, a powerful supporting point for the other two battalious in the case of their being driven back; while, on the other liand, from it the enemy, posted on the heights on the other side of the Huisne stream and on the heights of $I_{s e}$ Luard, could be held in eleck and prevented from debouching.

'The position was occupied as follows:-The lst company was posted at tl:e bridge over the Hnisne and in the mill building situated there; the 4th was in the chatean, and the third in the outbuildings aljoining it. The 2nd cowpauy was posted in rescrpe behind the châtenu.

The whole of the buildings wero prepared for defence in the most approved mauner, and shclter trenches constructed at appropriate points.

About 2 o'clock the 2nd and 3rd companies were despatched to the assistance of the $2 \mathrm{nd}$ battalion.

$\Delta$ lively fire, both of musketry and artillers, was maintained on both sides throughout the day. The enemy sent forward a thick skirmishing lino aguinst tho bridge; but the attempt was easily repulsed.

Nightfall brought the fight to a close along the whole line.

Late in the erening the regiment was despatched to its quarters in the farms north-cast of Changé, which were reached at $\mathbf{2}$ o'clock in the morning of the 12th January.

The losses of the regiment wers:-Killed, 3 Ofiecrs, 7 non.commissioned officers, 33 men; wounded, 7 Officers, 11 non-commissioned oflicers, and $85 \mathrm{mcv}$.

The final decision at To MInns itself had yet to be fought out. The rest of the forco had also gained ground, and reached forward positions towards that place.

At 6 ..x. the regient was turned out, as the cnems had attacked the outposts.

On assembling it numbered only $1 \check{5}$ Officers and a littlo orer 1,000 men. The 2nd battalion was broken up, and two companies were attached to the lst and two to the fusilier battalion.

The 6th Division remained the whole day in readiness at Change.

About 6 r.3r. news reached that place that Le Mlans had been captured in the course of the afternoon by the Xth Corps after severe fighting.

The losses of the whole Army between the 6th and the 12th January was 189 Ofticers and 3,450 men killed and wounded. Of these numbers, 127 Officers and 1,771 men belonged to the IIIrd Army Corps, which had the severest portion of the fighting. 'The actual capture of Lo Mans, on the 12th Jnnuars hy the Xth Corjs, was cffected with comparatively small losses, and resulted in 22,000 prisoners being made, and the rest of the French 2nd Isoire Army dispersed.

'The regiment entered Lo Mans on the 16th January, and receired there on the following day a convoy of 64.4 Firsatz men, comvalescents, and Frsatz recraits; 155 had been left sick on the was owing to the extreme cold. 
On the arrival of this convoy the battalions wero again organized in four companies. Of tho 12 companies, 3 were commanded by lirst. I ientenants, the remainiug 9 by- Second Lieutonants.

The reginent remained at Le Mrns until the 23rd Jaunary, when it mored out to relieve the Xth Corps, which, with the IIIril Corps, was forming tho adranced guard, and furnishing the outposts in front of the Loire Army".

Shortly afterwards the first arrnistice occurred, at the expiration of which, on the 20th February, the regiment had the following strength :-

Regimental Staff and 1st

battalion ............

ond battalion ............

Fusilier battalion .......

Oflicers. Non-com. JIusiciaus. Men.

$$
\text { Total ....... } \quad \frac{14}{149} \quad \frac{\pi}{\tilde{5} 6} \quad \overline{2,468}
$$

The armistice was prolonged successirely to the 24th February, the 27th February, and then to tho 12th March-after the Pence preliminaries had been signed.

Actiro operations were not resumed; but the 20th Regiment was destincd to remain a long time yet in France, as part of tho Army of Occupation. ${ }^{2}$

1 One of the features in the campaign was the constant changes in the commands of the companics, but time and space are wanting to put this in tsbular form. Discipline did not depend on personal relations between Oflicers and men, but on the ingrained habit of ohedience to rank, no matter who was the posscssor of the rank. I strongly recoumend those who in our own Serrice insist so strougly on the need for men to work under their "own" Offiecrs, or who adrocist. personal relations among "groups" in the ranks, to study the histories of the German regiments who did wost work in the c:ımpaign, and then tell us how their remarkable proposals would rork under similur circumstances.-LD. 